Portland State University

PDXScholar

1980

\title{
Public transit and student choice : a survey with Portland State University students
}

Sheku Gibril Kamara

Portland State University

Follow this and additional works at: https://pdxscholar.library.pdx.edu/open_access_etds

Part of the Geography Commons, Transportation Commons, and the Urban Studies and Planning Commons

Let us know how access to this document benefits you.

\section{Recommended Citation}

Kamara, Sheku Gibril, "Public transit and student choice : a survey with Portland State University students" (1980). Dissertations and Theses. Paper 2968.

https://doi.org/10.15760/etd.2962

This Thesis is brought to you for free and open access. It has been accepted for inclusion in Dissertations and Theses by an authorized administrator of PDXScholar. Please contact us if we can make this document more accessible: pdxscholar@pdx.edu. 
AN ABSTRACT OF THE THESIS OF Sheku Gibril Kamara for Master of Science in Geography presented October 21, 1980.

Title: Public Transit and Student Choice: A Study with Portland State University Students.

APPROVED BY THE MEMBERS OF THE THESIS COMMITTEE:

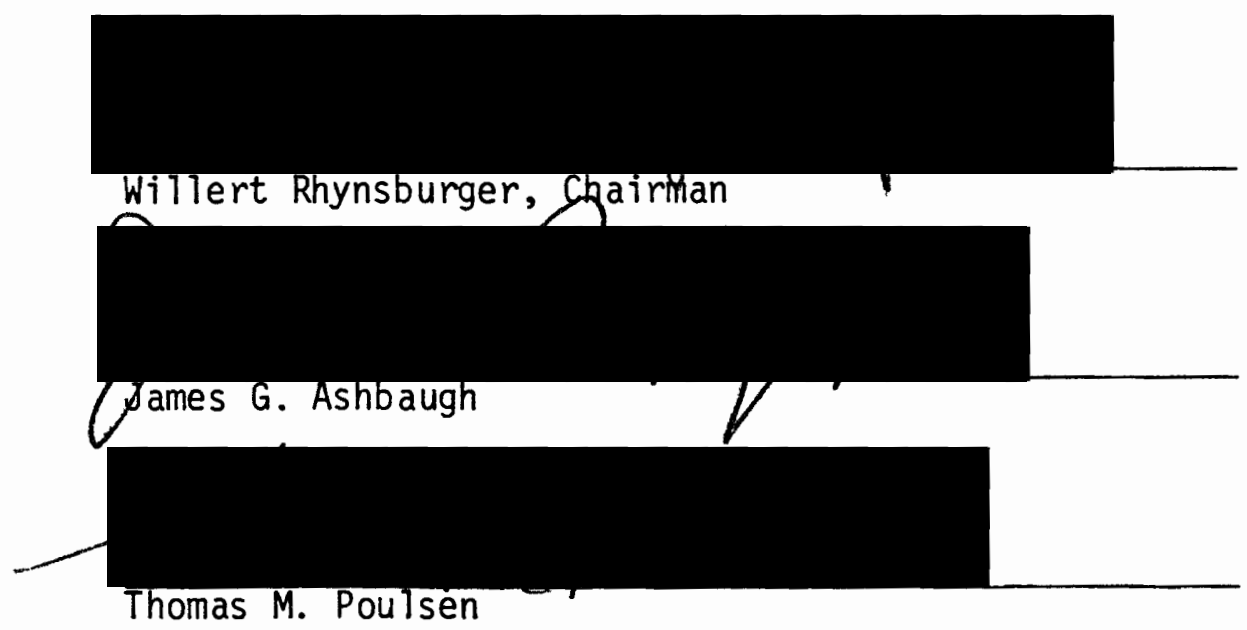

Research in urban transportation has been of many facets. Some have emphasized modes and routes while others have attempted to isolate and look at small segments of the transportation market with specific demands. Such segments include workers, recreation riders, and to a less extent, students. In the "journey-to-work" studies, a major finding has been that as income of workers increases, the distance between residence and work-place also increases.

This thesis starts with a series of hypotheses generated as a result of the findings of other studies reviewed in the literature. 
In testing the hypotheses, variables that are likely to influence student transportation cost and mode-choice in the Portland State situation were identified and included in a survey questionnaire administered among Portland State University students. The identified variables include, among others, student income, course load, duration of occupancy of dwelling unit, distance from school, time taken to cover that distance, and type of mode commonly used. In addition to the questionnaire survey, informal interviews were held with school and public transit authorities.

Tha data were analyzed by simple cross-tabulation as well as through the use of multiple linear regression and discriminant analysis. The regression technique was used in the prediction of transportation cost. The statistically significant variables were used in the discriminant analysis for mode-choice classification.

In the prediction of transportation cost, four variables were most influential. These are respectively income, duration of occupancy of residential unit, distance, and course load. In the mode-choice classification, the most significant single variable was course load. It is concluded that student income and course load are the most important determinants of transportation cost and mode selection. Secondly, public transit is the cheapest means of mechanized transportation for PSU students. Currently, the survey indicates that nearly half of the students use public transit, but with increasing route interconnections, this proportion is likely to increase. Students 
from the north, northeast, and southeast sections of the city seem to be better served by public transit than those in the west. The westward extension of the proposed light rail transit or the establishment of a major bus-way to Beaverton is also likely to increase the amount of student bus riders from the western section of the metropolitan area. 


\title{
PUBLIC TRANSIT AND STUDENT CHOICE: A SURVEY WITH PORTLAND STATE UNIVERSITY STUDENTS
}

\author{
by
}

SHEKU GIBRIL KAMARA

A thesis submitted in partial fulfillment of the requirements for the degree of

\author{
MASTER OF SCIENCE \\ in \\ GEOGRAPHY
}

Portland State University

1980 
TO THE OFFICE OF GRADUATE STUDIES AND RESEARCH:

The members of the Committee approve the thesis of Sheku Gibril Kamara presented October 21, 1980.

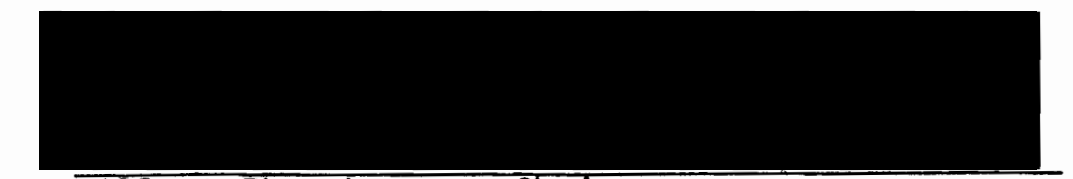

Willert Rhynsburger, Chairman

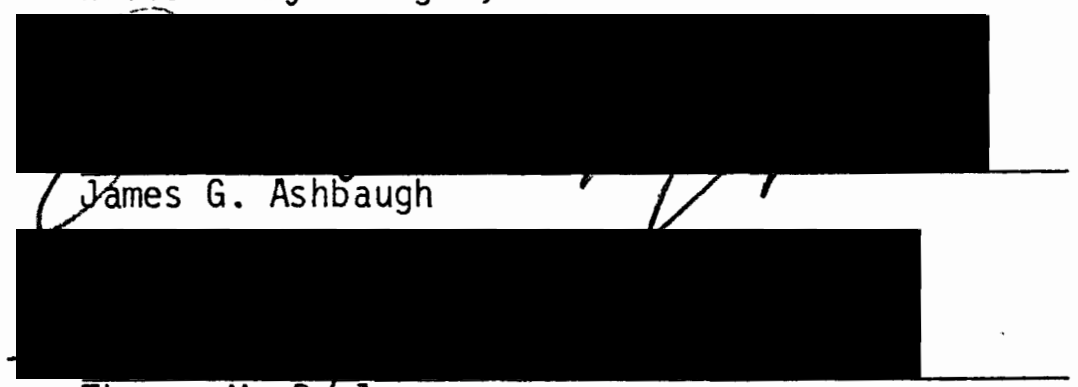

Thomas M. Poutsen

APPROVED :
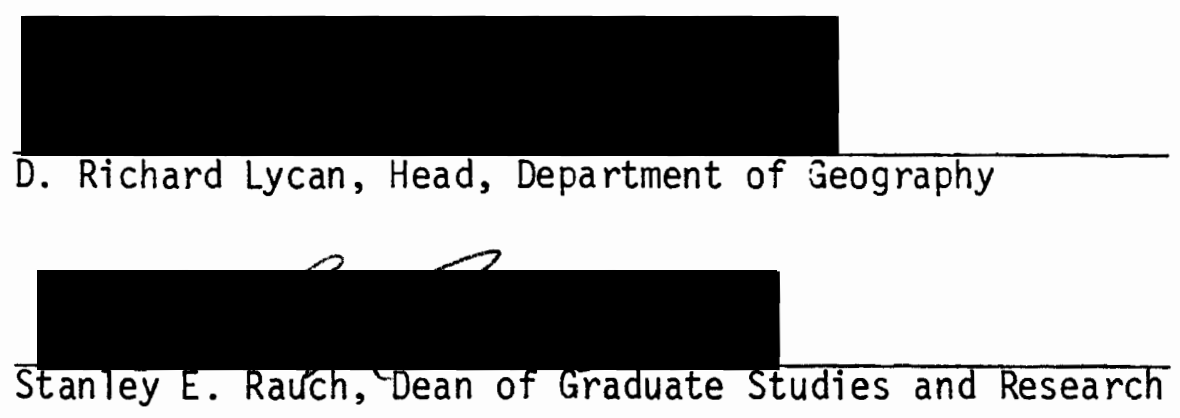
TABLE OF CONTENTS

PAGE

LIST OF TABLES

LIST OF FIGURES

vi i

CHAPTER

I INTRODUCTION $\ldots \ldots \ldots \ldots \ldots \ldots \ldots \ldots \ldots \ldots \ldots \ldots \ldots \ldots \ldots \ldots \ldots \ldots$

The Problem $\ldots \ldots \ldots \ldots \ldots \ldots \ldots \ldots \ldots \ldots \ldots \ldots \ldots \ldots$

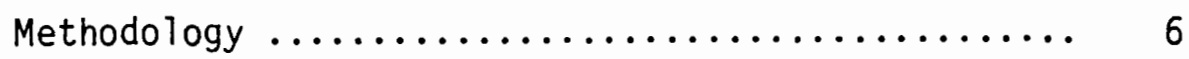

Review of Literature $\ldots \ldots \ldots \ldots \ldots \ldots \ldots \ldots \ldots \ldots$

I I DESCRIPTION OF CURRENT STUDENT TRANSPORTATION MODES $\ldots \quad 12$

Walking to school $\ldots \ldots \ldots \ldots \ldots \ldots \ldots \ldots \ldots \ldots, 12$

Bicycles and Motorcycles ................. 16

The Private Car ......................... 20

The Public Transport System (Tri-Met) ......... 20

Transportation Services for Handicapped Students .. 22

II I THE DEVELOPMENT OF PUBLIC TRANSIT IN PORTLAND $\ldots \ldots \ldots .24$

The Portland Traction Company (Oregon) ........ 25

Rose City Transit Company (RCTC) ........... 26

The Tri-Metropolitan Transit Corporation (Tri-Met) 28

Administration, Machinery and Operations ........ 31

Transportation Zoning .................... 35

Other Services $\ldots \ldots \ldots \ldots \ldots \ldots \ldots \ldots \ldots \ldots \ldots \ldots$

Demand-Responsive Services ............... 37

Tri-Met's Long Range Objectives ............ 38 
IV STUDENT TRANSPORTATION SURVEY AND ANALYSIS $\ldots \ldots \ldots \ldots .41$

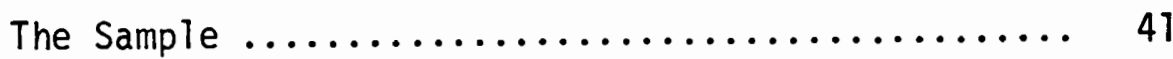

Content of Survey Questionnaire ............ 42

Survey Results ........................ 44

The Distribution of PSU Students in Portland ..... 44

Relative Use of Different Modes ............ 50

Cost of Transportation and Mode $\ldots \ldots \ldots \ldots \ldots \ldots .50$

Cost of Transportation and Distance ........... 52

Cost of Transportation and Time ............ 55

Employment and Income $\ldots \ldots \ldots \ldots \ldots \ldots \ldots \ldots \ldots, 55$

Location of Residence and Income ........... 55

Distance from School and Income ............. 58

Analysis of the Data .................... 60

Multiple Linear Regression ............... 61

Discriminant Analysis $\ldots \ldots \ldots \ldots \ldots \ldots \ldots \ldots \ldots 64$

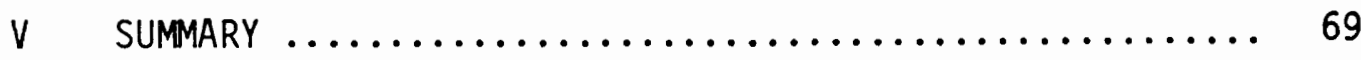

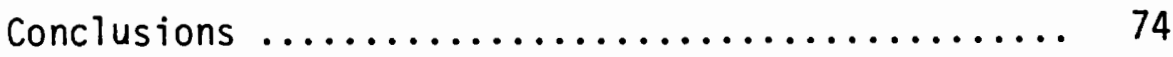

Suggestions for Future Research ............ 76

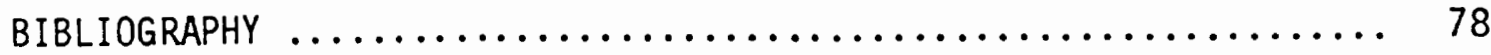

APPENDIX: THE SURVEY QUESTIONNAIRE $\ldots \ldots \ldots \ldots \ldots \ldots \ldots \ldots \ldots \ldots \ldots$ 


\section{LIST OF TABLES}

TABLE

PAGE

I A Comparison of Finances, Services and Passengers

from the Three Counties $\ldots \ldots \ldots \ldots \ldots \ldots \ldots \ldots, 32$

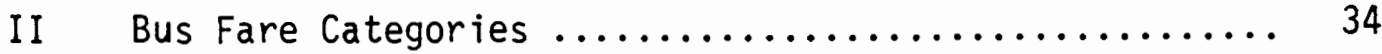

III Distribution of the Sample Among Majors of Various

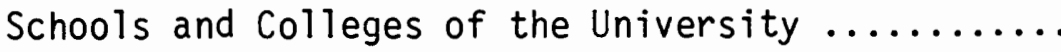

IV Population of the City of Portland by Section

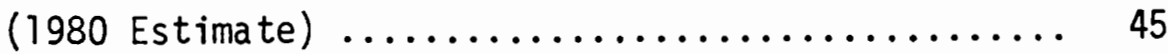

V Changes in Total Student Enrollment in PSU Since 1975.

VI Numbers of Students Attending PSU from Sections of

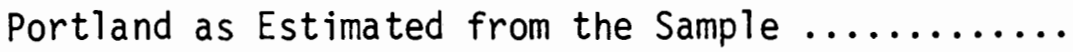

VII Calculated Concentration Coefficients of Students in

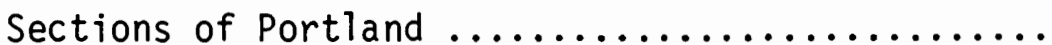

VIII Relative Use of Transport Modes ............... 52

IX Relative Costs of Transport Modes ............... 53

$X \quad$ Mean Distance and Cost of One-Way Transportation

(Including Daily Parking) $\ldots \ldots \ldots \ldots \ldots \ldots \ldots$

XI Income Versus Location of Residence ............. 57

XII Employment Versus Residential Location ............ 58

XIII Income Versus Distance ...................... 60

XIV Multiple Linear Regression: Transportation and Parking Cost Against all Variables. 
XV Relative Power of Discriminant Functions for Mode Choice 65

XVI Standardized Discriminant Function Coefficients ....... 65

XVII Prediction Results ........................... 67 


\section{LIST OF FIGURES}

FIGURE

PAGE

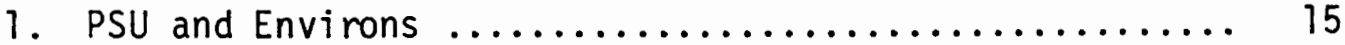

2. Portland Metropolitan Area - 1970 Census Tracts ...... 46

3. Percentages of Population and Students in Sections of Portland $\ldots \ldots \ldots \ldots \ldots \ldots \ldots \ldots \ldots \ldots \ldots, 48$

4. Percentages of Students Using Different Modes ........ 51

5. Cost of Transportation and Distance ............... 54

6. Cost of Transportation and Time $\ldots \ldots \ldots \ldots \ldots \ldots \ldots . . . \ldots$

7. Distance from School and Income .................. 59 


\section{CHAPTER I}

\section{INTRODUCTION}

Transportation is one of the numerous processes concerned with circulation within a system. ' It is probably the single, most important component since it establishes the type and nature of physical contact existing between people in different places. Many models used in urban geography, such as the gravity model, ${ }^{2}$ reasonably predict interaction using population and distance figures. Such models, are useful for prediction in so far as interaction between major settlements is concerned. Even so they make many generalizations; for instance, in some cases every element in the population is treated equally. Children, youth and retired people, as well as the rich and poor, are regarded as having equal opportunity, desire and propensity to travel or interact. In this regard, these models fail to consider the attitudes and limits of the interacting groups in the system studied.

Here circulation is defined as the sum total of the processes involved in the flow of goods, people and information in a system.

2 The gravity model, developed initially on a formula based on Newton's law of gravitation, predicts interaction by using the masses (populations) of places and the distances separating them. A gravity model can also be designed to select input variables suitable for the particular study; e.g., people above a certain income level, people within a certain age group, or a combination of many factors (Hammond and McCullagh, 265-269; Chorley and Haggett, 1967, 559-561). 
Practical case studies of circulation subsystems, the use of specific modes by select groups of people, are required in order to establish understanding of spatial relationships within an urban area. These studies serve to indicate the nature of spatial organization and associated problems concerning the accessibility of primary activity centers. Such empirical studies are of value in two important respects: firstly, they go a stage further than probabilistic or simulation models by considering actual practical problems rather than theoretical relationships derived from statistical assumptions. Secondly, these studies also consider the behavioral and socio-economic circumstances of the subjects themselves.

Within major urban settlements in the United States the location of such traffic generating points as schools, shopping areas, and medical establishments is directly related to the public transit system, with services organized from one point to another, or from the city center to each of the various points. Individuals however - actors in the urban circulation system - may or may not live adjacent to public transit routes. Or even if available, the route may not be direct and a person may end up spending twice as much travel time and over twice as much travel distance as he would if using a different means of transport and route. In addition the particular employment opportunities or personal wishes of some students may determine the use of different means of transport, and perhaps only a small proportion regularly use public transport even though the route connection may be good.

The City of Portland is the largest urban unit in the state of Oregon. 
It is situated on the banks of the Willamette river, not far from the confluence with the Columbia river. The population of the city is about 385,000 (1980 estimate). Portland is the "central city" of a metropolitan area - the U.S. Standard Metropolitan Statistical Area including Vancouver (Washington) and the major Oregon communities of Gresham, Milwaukie, Oregon City, Lake Oswego, Tigard, Beaverton, Hillsboro and Forest Grove - roughly totaling 1,080,000 people. The central city and most of the populated parts of the metropolitan area are served by buses of the Tri-County Metropolitan Transit Corporation (Tri-Met), which has the responsibility of operating public transportation services throughout the urban area. Portland CBD (central business district) is located on the west side of the Willamette river. Its expansion, as well as that of the residential area to the west, is limited by the west hills (which nevertheless constitute some of the city's high-income residential districts). The bulk of the residential areas of the city, therefore, lie on the east side of the river. The present study concerns only the city of Portiand and does not consider transport in the suburban ring.

Portland State University is located on the fringe of the Portland $C B D$, approximately ten city blocks southwest of the city center. The campus is situated with in "Fareless Square", a free bus zone created by Tri-Met to enhance easy mobility in and around the CBD. Student population in the university fluctuates around an average of approximately 16,000 , most of whom have at least part-time job engagements either at school, at home, or in some private or public agency within the locality.

Many interrelated factors influence the decisions of students as to 
what form of transport to use to go to school. An understanding of these factors would reveal many spatial patterns. For example, a study of the movements of select groups of students from various sections of the city to one institution, or the sum total of all movements of all the students attending the same school, would reflect the accessibility of that institution to/from particular places. In the case of Portland State University, since it is located close to the city center and draws students from throughout the metropolitan area, the patterns would probably reflect the connectivity of places via the city center in what one would suspect as being a radial transport network.

\section{The Problem}

The problem that this thesis attempts to study may be stated in two questions. These are: (1) What are the major factors that account for the cost of student transportation in Portland State University, and (2) what are the relative influences of these factors on the choice of transpoirt modes by students.

Prior to the investigation of these questions, as background understanding, the different transport modes currently used by the student market segment and the development of the public transit system will be studied in chapters II and III respectively. The major focus in these chapters will be in the area of the relationship between the location of the school and the use of specific transport modes. Six modes will be considered. These are: (1) walking, (2) the bicycle, (3) the motorcycle, (4) the private car, (5) public transit, and (6) 
special modes which include carpool and demand-responsive services. 3 In addition, the local jurisdictional and administrative problems and advantages which affected the development and routing system of public transit in Portland will be investigated in chapter III.

The major investigation of the problem is covered by the survey and analysis in chapter IV. In order to generate the required data for that analys is eight hypotheses were postulated which will be tested in the survey. These are as follows:

(1) that cost of transportation is directly related to the type of mode used and the distance covered.

(2) that choice of mode is related to cost, distance and student income.

(3) that student income is related to distance.

(4) that travel time is inversely related to transportation cost.

(5) that the Fareless Square around downtown Portland has a direct influence on student choice of mode.

(6) that the longer a student stays in a particular section or neighborhood in the city the lower his transportation cost tends to be.

(7) that the frequency of bus service is related to the choice of mode.

${ }^{3}$ Demand-responsive services (DRS) are defined here as those services which are provided exclusively for handicapped and/or disabled students. These are route-, time-, and sometimes passengerspecific. 
(8) that student course load is related to the student's consistency of modal use.

\section{Methodology}

Data were gathered primarily by administering an adjusted questionnaire to students in geography classes at Portland State University during Fall quarter, 1979. The total number of questionnaires originally handed out totalled to approximately $3 \%$ of the entire student population. With the consent of the professors, the questionnaires were completed during class sessions with special caution taken so that students taking more than one departmental course did not fill out more than one questionnaire. In addition, direct interviews were held with other special students such as handicapped or otherwise disabled ones who seemed to pose special transportation problems, and also seemed to have been left out of the sample. Informal interviews were also held with certain personnel of Tri-Met as well as with other university authorities concerned with transportation.

The data collected were analyzed by cross tabulation and by using simple multi-variate statistical techniques and the Honeywell computer services of the university. The statistical techniques were firstly, the use of multiple linear regression to determine whether any linear relationship existed between cost of transportation to school (including daily parking expenses where a car or motor-cycle are used) and distance, time, income level, duration of occupancy of dwelling 
unit, and school course load. Secondly, the technique of discriminant analysis was used to determine mode-choice by attempting to group the subjects into major transport mode categories.

Review of Literature

There has been little work done at the dissertation level on student transportation. Most of the studies done on urban transportation deal with area-wide transit systems alone. In addition, a few studies have focussed on specific transit services created to supplement the existing private and public transportation means of specific areas, such as those serving two campuses of the same establishment, or shuttle trips between a certain point in the city and a major activity area. One of the most recent of these studies was by willard (1977) on the techniques of data collection for a transit study at a major activity center, with a case study of campus transportation at the University of Maryland. ${ }^{4}$ Such studies as this one have emphasized how people get from one sister campus to the other but not on how they get from home to school, which could be more important, especially where home and school are separated by an appreciable distance.

In an article on commuter transportation in greater Montreal,

${ }^{4}$ Willard defines a major activity center (MAC) as a traffic generating area, with considerable internal circulation vital to its existence, and whose affairs are directed by a central administrator. Some examples of MAC's are airports, isolated shopping centers, medical establishments, military bases, recreation parks, and universities. The functions of the MAC should be important enough to attract the planner to expend special effort to solve problems associated with the center. 
Scarlett (1971) discussed among other things the decisions of private auto drivers and the choices they make from among many competing routes leading to different places in the city, in a stress situation such as after a snow storm. Using dynamic programming, the author then tried to find what would be the optimal route (in terms of distance, time, risk of accident, or the risk of failure to get to work) under conditions of shock.

Hecht (1974) made studies on the journey-to-work distance with special reference to the socio-economic characteristics of the workers. In an empirical case study in Worcester, Massachusetts, the author operated a multiple linear regression analys is which found that the distance between residence and work-place increased with increasing income of industrial workers. Hecht's analysis introduces a relevant premise for the present study: that even though this research focuses on students rather than industrial workers, an appreciable proportion of the students would be full-time or part-time workers, a condition coincident with the unique urban location of Portland State University, in comparison with traditional university campuses that may be located quite some distance from the job-generating city.

Reviewing various social science contributions on transportation research, McFadgen (1975) made a detailed appraisal of psychological factors such as attitude, perceptions and values of people in modechoice based on the findings of various researchers. ${ }^{5}$ Most of the

${ }^{5}$ Note that mode here is used to mean any of the five major ways of transport: road, rail, air, sea and inland waterways. Note also that later in the study mode may also be used to mean any means of transport. 
research work reviewed was large-scale, focussing on all modes of transport, and attempting to assess, measure and evaluate those attitudes, values and attributes linked with the choice of a particular mode.

In a transportation study undertaken in Portland, Bahls (1972) reported that $70 \%$ of the faculty, staff and students of Portland State University utilized the automobile to campus. Of these $48 \%$ drove directly to school, $4 \%$ drove to three remote parking lots located at Portland Memorial Coliseum, the Portland Zoo, and Westgate Theater in Beaverton (with a capacity of 1,400 cars) and then a shuttle bus to the university while the rest rode as passengers. Tri-Met bus users were reported to be only $15.7 \%$, while $11 \%$ walked a11 the way to school. The report concluded with recommendations not only to increase park-and-ride facilities but to increase campus parking facilities as well as to re-schedule some classes to off-peak hours, so that more people will have access to the parking structures and at the same time others may be encouraged to use public transit during off-peak hours.

In the 25 year-period preceding 1970, transportation demands in the Portland urban area grew steadily. The labor force increased significantly in each county (especially Multnomah) indicating transportation needs for more people, but public transit patronage dropped at a very fast rate (Columbia Region Association of Governments, 1974a).

As a policy goal the regional organization, the Columbia Region Association of Governments, was determined to reduce the high demand for transportation by shifting the emphasis from auto to other forms 
of transportation with a much greater reliance on well planned public transportation. ${ }^{6}$ Hearings held in December 1973 on the recommendations of the Public Transportation Master Plan proposed for 1990 led to the adoption of a resolution on January 31, 1974, to support a public bus rapid transit system and to study the possibility of alternative modes in exclusive corridors to places like Gresham, Oregon City, Hillsboro, and Forest Grove (CRAG, 1974a). In addition to the regular passengers and people requiring movement CRAG estimated a total of 87,000 "transportation handicapped" persons defined as the elderly and the handicapped (CRAG, 1977). New plans undertaken by CRAG (now pursued with modifications by MSD) sought to co-ordinate public transit on a regional basis and to improve and expand existing special transportation systems for the handicapped.

Among the many transportation areas to which the CRAG region was divided are four subareas within the city of Portland. These are Inner Southeast, Inner Southwest, Northwest, and Inner Northeast (CRAG, $1978 a, b, c, d)$. Each of these poses problems that are in some way different from those of other regions, and therefore requires special study.

While CRAG and MSD have done (and MSD is still undertaking) very valuable transportation research, a good deal of the research relates only to public transit, and with primary consideration of the

${ }^{6}$ The Columbia Region Association of Governments (hereafter referred to as CRAG) was superseded by the Metropolitan Service District (hereafter referred to as MSD) in January, 1979. 
transportation handicapped. Other communities of people are not isolated for study either by neighborhood or by institution.

In this regard, it is necessary to review the modes used by PSU

students and compare them against the services provided by public transit. This review is done in the next chapter. 
CHAPTER II

DESCRIPTON OF CURRENT STUDENT TRANSPORTATION MODES

Depending on their physical location and the choice decisions they make, students attending Portland State University have several means of transportation available to them. These transport means may be broadly categorized into two types: pedestrian and yehicular. Vehicular modes include the bicycle, motor-bicycle, motorcycle, the private automobile, the public bus (Tri-Met), and what has been categorized in this study as special means.

\section{Walking to School}

Walking to school is the most economical and readily available means of transport. However, to make this choice, four conditions must be reconciled with. These are:

(a) Distance - The effect of distance on walking is an inverse relationship. That is, if the distance between home and school is short one is most likely to walk. The longer the distance, the less willing one becomes to make the decision to walk even if the road condition is amenable to walking.

(b) Time - The importance of time is directly related to the availability and frequency of an alternative mode. Even if the

'Special means refers to such services as DRS and carpool which serve either restricted numbers or people in special need. 
distance is long, when the time factor involved in waiting for and riding an alternative mode is longer than it would take to walk, one is more likely to choose the latter.

(c) Alternative mode - Where there are other readily available modes, and given that route connections and conditions are equally good, walking may be the least likely choice. In some instances, however, there may be no other means of transport; a rare but important condition especially in places of poor network connectivity. Walking as an alternative mode may involve covering short distances to change a bus, or to catch another ride in a mixed mode system.

(d) Safety - Distance and walking-time may be short. In addition the cost of using an alternative means may be high. Yet the latter may be the safest means available in making the journey to school. Depending on the location of the school, safe pedestrian walkways could be very encouraging in influencing mode-choice decision making.

The safety of sidewalks is important especially in an inner city location where traffic is heavy and many times fairly rapid. According to Jacobs (1961), "When people say that a city, or part of it, is dangerous or is a jungle what they mean primarily is that they do not feel safe on the sidewalk." The safety of a street is also related to the clarity of the demarcation between street and sidewalk, 
a flow in the continuity of the number of users, and the attractions or distractions along the street (Jacobs, 34 ).

One major important point on safety is the availability of adequate walkway facilities ${ }^{2}$ for both pedestraians and wheel-chair users. It is worth noting here that the walkways of streets within and near the Portland CBD have been readjusted to accommodate wheel-chair users.

Although PSU is located close to the city center and actually competes for space with commercial establishments as well as highrise apartment houses such as Ione Plaza and Park Plaza, and though it may lack the formal outlook of a traditional residential university's campus, there are nevertheless twelve student houses operated by Portiand Student Services (PSS) ${ }^{3}$ close to the campus. Most of these houses are within 15 minutes of walkable distance from school (Figure 1). These houses provide accommodation for approximately 2,000 students, and roughly 1,500 of these attend P.S.U. There are quite a few houses close to school which provide residential accommodation to other

2The availability of adequate facilities for pedestrian movement reflects on the number of users. The adequacy of pedestrian walkway facilities has been investigated and some recommendation have been advanced for a section of the city of Portland.

3 Port land Student Services (PSS) is a non-profit organization which is administratively separate from PSU, founded in 1969 and operating housing for students. It is operated by a seven-member board of directors which includes four student tenants and three community leaders who make policy decisions necessary for the running of the business. Housing facilities are located near PSU and the University of Oregon Heaith Sciences Center but serve as well students attending other colleges in the Portland metropolitan area. 


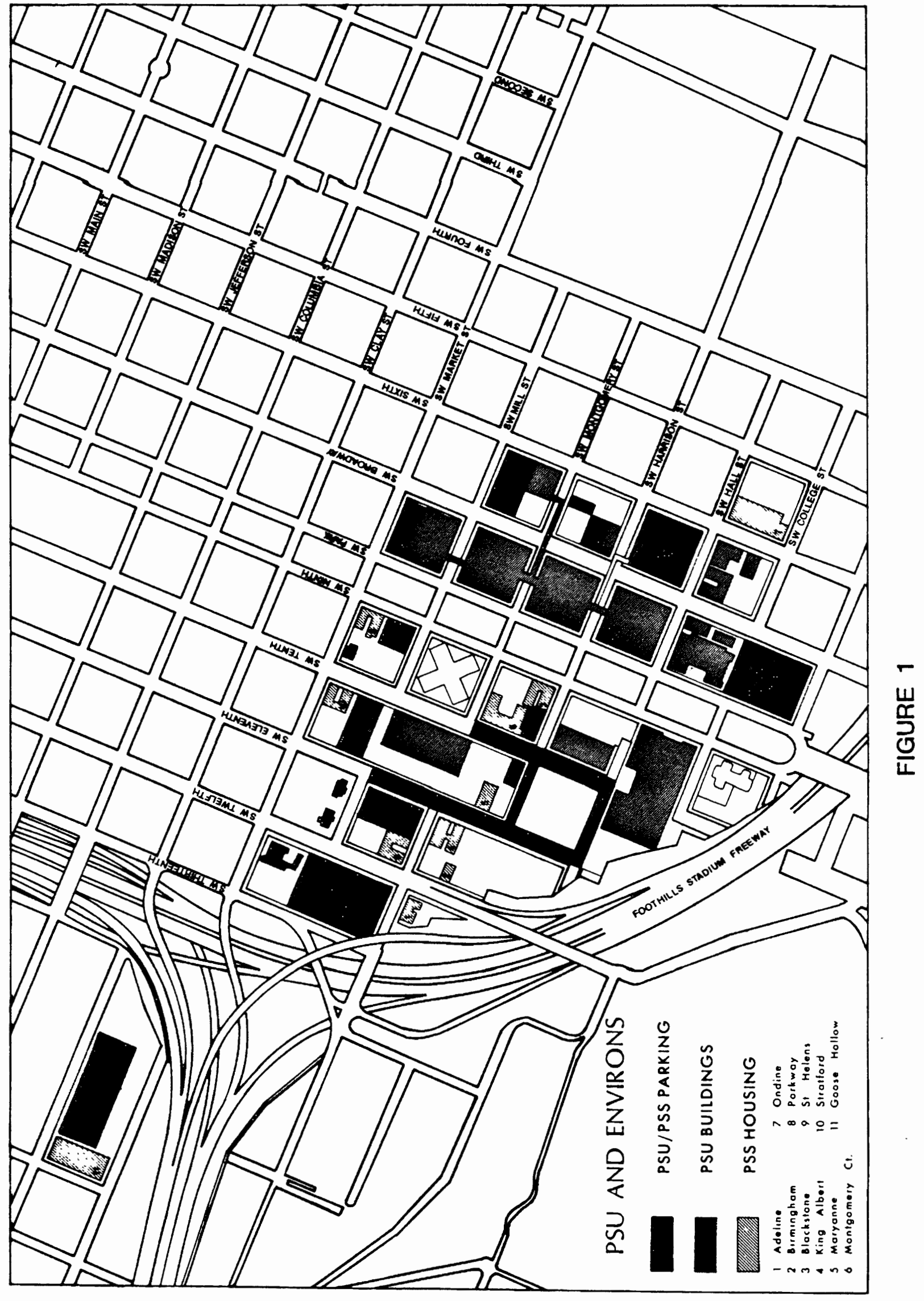


students, and in addition, some richer or foreign students compete with Portlanders for the use of the more expensive apartments. PSS houses have facilities for married and single students, students with children, and for students with special disabilities or handicaps. Apartments include one and two bedrooms, efficiency and sleeping rooms.

\section{Bicycles and Motorcycles}

The use of the bicycle in American cities increased greatly during the 1970s. For some people it is a means of recreation. To many others it provides a good and economical substitute to the automobile, whose pollution problems and cost of operation are increasing tremendously. Skeptics, however, are of the opinion that the intensive energy-use and high respiratory activity associated with the bicycle will be a deterrent to its use on a wide scale. It provides privacy, that is, used only by one (rarely two) at a time, yet it exposes riders to high pollution concentrates of such substances as carbon monoxide (CO), various oxides of nitrogen and hydrocarbons, increasing their toxic levels in the blood within a shorter time than any other mode would, all other conditions remaining equal. However, the fact that it takes up much smaller channel and parking space, uses little or no fuel energy, and produces no pollution means that the bicycle can be a viable substitute to the automobile especially where terrain conditions are conducive to its use. 
The safety of bicycling is a serious concern in urban areas. This chiefly involves conflict between bicycle drivers and pedestrians (whom they invariably surprise from behind, when they share the same route) as well as with automobile drivers, who often have difficulty in judging where a bicyclist will make a turn as he cannot easily signal his intentions. The greatest bicycle dangers in urban areas are associated with automobiles at intersections, and according to past studies, "confrontation with the automobile cannot be avoided in an urban setting even if bicycle paths become common." (Portland Bicycle Paths Task Force, 16).

Another consideration in bicycling is the discomfort and inconvenience associated with it. The high respiratory activity leads to intense perspiration, frequently requiring a bath at the destination and changing of clothes. Because of this, young executives, who have to wear suits to work, and some students who have to rush to class find it very inconvenient to use.

Effective bicycling in and around the city would result from either the proper utilization of pedestrian sidewalks or the construction of special bike-routes. The former choice is more likely and in fact appears to be more acceptable to cyclists who think they should share in the observing of traffic regulations just like motorcyclists or automobile drivers (Barber, 7). However, depending on the nature of the urban environment and the prevailing limiting factors, either alternative may be equally practicable. In the city of Portland, there are two unique physical limitations. 
These are the Willamette River and the West Hills. While the West Hills seriously deter bicycling to a large extent, bicyclists may, on the other hand share sidewalks along the numerous bridges across the river. As a policy, plans for bicycle facilities tend to favor the construction of separate bicycle paths in various sections of the city. The closest of these paths to PSU is one constructed "... along an existing path between S.W. 17th Avenue and S.W. Montgomery Street known as the Goose Hollow Trail in freeway right of way." (Portland Bicycle Paths Task Force, 29). The half-mile Goose Hollow track adjacent to I-405 (costing over $\$ 36,000$ to construct) generated a monthly average daily traffic of 36.2 trips (one way count) for the period of January through September, 1974 (Oregon Department of Transportation, 1975, 79), which is just one-third of what the Highway Division thinks should be the minimum useage to justify the construction of a bikeway (Oregon Department of Transportation, 1973, 41).

Although bikeways have proved to be very expensive regarding the very low traffic density, and even though there are numerous problems associated with bicycling safety, comfort and convenience, bicycle use is likely to increase among Portland State students facing problems concerning the alternative modes. ${ }^{4}$ A further encouragement could be provided by the public transport system through adding

${ }^{4}$ A student transportation survey at Portland State University found that only approximately one percent of the students rode bicycles to school (Barber, 10). 
buses adapted to accomodate bicycles as a step towards encouraging mixed-mode transportation. 5

Motor-bicycles face the same situations and problems as ordinary bicycles do. However in Portland there seem to be far fewer motor-bicycles in use than either bicycles or motorcycles probabiy because even their speed, safety or comfort are hardly superior to those of the ordinary bicycle, even though they involve substantialiy higher maintenance costs.

The motorcycle appears to present all the problems associated with the automobile at a rather smaller scale. In addition, motorcycle ridership is manifestly more exposed to the risk and the danger of accidents than even the bicycle, and this is probably the main reason why fewer people use it. As a competitor of the bicycle, the motorcycle inheres gasoline costs, licensing, and traffic constraints (including parking) just like the automobile. In this regard, its maintenance costs are high and user returns (or benefits) per person per mile are low. Its advantages however, are great for those students who do use it since, like the private vehicle, it is always available at the user's convenience and it is either as fast or faster than an automobile.

${ }^{5}$ AC Transit of Oakland; California is experimenting with a bicycle bus called the "pedal hopper" between Oakland and San Francisco. This is being tried since the Bay Bridge has no bike facilities. However, this experiment has not been feasible financially as it is very expensive (Balshone, 48). 
The Private Car

Much of the cause of what urbanists and urban geographers have come to call the "decay of the inner city" is attributed to the motor car and its associated problems. The private car has caused more serious pollution problems in the city than in the country. In the U.S., city-center development in the early twentieth century made little or no allowance for automobile parking conveniences. Growth in private car ownership has outweighed the increase in availability of parking spaces. Until fairly recently, parking structures had little vertical expansion as did the business buildings.

The Portland CBD and the PSU campus have had parking problems no less than those of other American cities. When school is in session, PSU parking facilities are never sufficient and this is a personal inconvenience to those students, professors and other staff on campus who opt to use the private car in favor of another form of transportation.

The total number of available parking spaces for cars at the P.S.U. campus is approximately 2284 in two major parking structures (a third is under construction). Of these, 251 are reserved and carpool spaces whereas 20 are loading and offloading zones. Motorcycle parking spaces number about 70, bicycles between 100-150. Spaces reserved for motorcycles may however take at least two each.

The Public Transport System (Tri-Met)

Public transit in the Portland metropolitan area is provided by 
the Tri-County Metropolitan Transport District. It is a public corporation providing bus service in the City of Portland, and to neighboring cities of the urban area. Under a special arrangement, service is extended to Vancouver in Washington State. Tri-Met has taxing rights and receives a federal grant to subsidize its operation costs. Other important transportation services provided by Tri-Met are buspools, carpools, and vanpools. A buspool involves a special express bus service for people who start or leave work at times when regular buses are not available. It differs from the regular service in that riders can be picked up from their neighborhood or park-andride lot, and then the bus travels via a fast custom-tailored route to the work site. Large employers or groups of people may make the negotiation with Tri-Met which in turn finds out whether there are enough people to use the service beneficially. Carpool service may be provided for any three or more people living in the same neighborhood who wish to ride together and share nas or other costs. Tri-Met provides a monthly carpool parking permit (which enables carpoolers to park at any downtown six-hour meter all day for a monthly fee) as an incentive to carpool users. Such facilities may be also be instituted at other locations. Additional facilities include the free use of any of the 63 park-and-ride lots available throughout the tri-county area.

Vanpooling is very much like carpool. The only difference is that vanpoolers ride in a van which carries more passengers. While a few students may be using carpool quite satisfactorily, a reasonable amount of vanpooling has also been undertaken by student 
groups mostly for field trips and excursions to places within or outside of Portland.

Transportation Services for Handicapped Students

As a policy, Tri-Met is expected to provide services for handicapped or otherwise disadvantaged people who may wish to use public transportation. Tri-Met's special branch that fulfills this purpose is "Lift" service. This service comprises a fleet of minibuses, each equipped with a special lower step for getting on and getting off easily, a separate lift and tie-down space for wheel chairs with optimum safety and comfort, and convenient door-to-door service to the users.

According to interviews with some disabled students at PSU, other agencies such as Care-Car also provide door-to-door transportation for them. One major problem however, is that the time range (between when the buses pick them up at home and when they are picked up at school to return home), is so short that users are prevented by the time constraint from taking important courses that they would otherwise desire to take. One such bus picks up the passenger at home at $10.00 \mathrm{a.m}$, and then at school for the return journey at 2.00 p.m.

In sum, the facilities for transportation to PSU are many and varied. Some facilities are not particularly convenient, but are much cheaper than others. Others may be costly but very convenient. Yet others may be a combination of the two extremes. The choice of 
a particular mode by an individual student thus depends on several interacting factors, which are to be determined in later sections of this study. That determination, however, requires an overview of the development of public transit in Portland. This is addressed in the next chapter. 


\section{CHAPTER III}

THE DEVELOPMENT OF PUBLIC TRANSIT IN PORTLAND

The City of Portland, like other jurisdictions in Oregon, was created by and is governed according to the Oregon Revised Statutes (ORS, vol. 2, 405). In subsection 902 of chapter 221 , provisions were made for "a city government whose membership comprises of the mayor, aldermen, a recorder, a treasurer, and a marshal of the municipal corporation (ORS, Vol. 2, 119), all of whom shall have to be elected to two year-terms of office. The election of the aldermen is staggered such that three go out of office at the end of each year."

The city council appoints at its discretion a city attorney a streets superintendent, a civil engineer and police chiefs for the city. Furthermore, the council has the power to:

"Permit, allow and regulate the laying down of tracks for streetcars and other railroads upon such streets as the council may designate, and upon such terms and conditions as the council may prescribe ..." (ORS, Yol. 2, 221).

Such favorable powers encouraged the development of several streetcar and railroad transit lines around the city of Portland in the 1890's and early 1900's. 
Between 1871 and 1956 at least 34 transit lines operated in different parts of what is now the Portland metropolitan area. Most of these lines were operated by privately-owned companies or partnerships, many of which had similar or identical names and overlapping periods of existence. Some, however, were merely holding companies undertaking very few or no operational services, while others were actually functional, serving small sections or subsections of the present urban area. Some of the companies became defunct even before completing their long gestation periods, while others were virtually quiescent during the greater period of their existence. Many however, were in use simultaneously, operating on single streets or street segments.

Problems of organization, maintenance, and insufficient financial returns forced many companies out of business. The property of one defunct group was most frequently transferred or sold to a successor group (as in the case of the transfer of Metropolitan Railway Company property to Portland Consolidated Street Railway Company in 1892). In some cases the property was sold to another already existing, more viable establishment, as for example the transfer of property of Portland City and Oregon Railway Company to Oregon Water Power and Railway Company on June 28, 1902. Both of these companies were incorporated in 1901 .

The Portland Traction Company (Oregon)

The last of the city lines which was operational prior to 1956 was the Portland Traction Company (Oregon), incorporated on July 25, 
1930, and operated by Cassius R. Peck, Earl S. Nelson, and Clarence D. Phillips (Tri-Met, 1979a, 7). This company was originally organized to hold and operate the urban (city lines) properties. This was the first attempt at unifying the transit lines in the city of Portland into one public transit system. The company inherited properties from Pacific Nortiwest Public Service Company on January 1, 1932. The Traction Company moved their central administration to East Burnside Street and S.E. 28th Avenue on March 7, 1940. Six years later, on August 29, 1946, the Traction Company went into liquidation and its property was acquired by Portiand Transit Company, which was a holding and not an operating company.

Rose City Transit Company (RCTC)

Ten years after the closure of the Portland Traction Company, Rose City Transit Company (RCTC) was incorporated on January 13, 1956. The property of Portland Traction Company including the East Burnside Street offices (which was acquired by Portland Transit) was transferred to RCTC on February 1, 1956. Under the auspices of RCTC the East Burnside offices were closed down on September 10, 1959 and the entire administrative and accounting departments were moved to 4100 S.E. 17th Avenue.

RCTC was a privately-owned and unsubsidized franchise. It was owned and operated by a California-based establishment. From 1946 RCTC operated the bus system in Portland with 205 buses on a trip fare 
of 25 cents. In January 1963 a ten-year lease franchise was granted to RCTC by the Portland City Council on the condition that the maximum net return of income (after taxes) obtained from passenger fares should not exceed $6.0 \%$ of operating costs. Further, the agreement was reached that if the city wanted to terminate the franchise, RCTC's property would be acquired at a fair value. Rose City remained smoothly operational for at least the next five years. According to the management of RCTC, increases in operational costs were such that an.. increase in passenger fares was necessary to offset the losses. By March 1967, it was granted a fare increase, bringing passenger fares up to 35 cents. The ensuing period, however, was one during which RCTC was poorly managed, with the bus drivers being among the lowest paid on the West Coast. The labor union was weak and thus had very inappropriate representation in meetings dealing with policy decisions affecting their conditions of service. In this regard, there was a general feeling of job insecurity and hence doubt about the future of the low level workers. The customers themselves were unhappy as bus service was inadequate because of fewer buses and routes. Equipment was also inadequate. The management of Rose City was thus in a dilemma. Mr. Charles C. Bowen, then RCTC president did not want to be placed under the jurisdiction of the public utilities Commissioner of the city, and at the same time the business was now disorganized and unreliable. In addition the discontented workers and drivers posed a strike threat. In the face of all these problems and for the second time in 20 months, RCTC again in 
November 1968 asked the city council for a fare increase of 5 cents more, bringing the trip fare to 40 cents. The City of Portland denied the increase, and in response to what it saw as the inefficiency, disorganization, and failure of RCTC to provide reliable transportation services to the people of Portland, the city council gave notice in December 1968 of termination of the franchise. RCTC resisted this order, arguing that a termination at that point was illegal. Instead, management asked again for the fare increase. A series of negotiations ensued during the following nine-month period, as a consequence of which the Mass Transit Advisory Commission of Portland offered $\$ 2.6$ million compensation for RCTC property and the company finally went into liquidation.

The Tri-Metropolitan Transit Corporation (Tri-Met)

The Tri-Metropolitan Transit Corporation of Portland, Oregon was organized officially on 0ctober 14, 1969. The corporation, which has been called Tri-Met for brevity, is a public corporation empowered to acquire, own and operate the public transit system in the Portland metropolitan area. Under the respective statutes, authority was granted to Metropolitan Service Districts in Oregon (and in this case the Portland MSD) to:

"... Provide public transportation and terminal facilities for public transportation, including local aspects thereof transferred to the district by one or more other public corporations, 
cities or counties through agreements in accordance with this chapter..." (ORS, Vol. 2, 929).

The service district within which Tri-Met was to operate includes Clackamas, Multnomah and Washington counties, whose boundaries are delimited as per two sections of the ORS. These are the boundaries of counties act (ORS, Vol. 2, 289) which delimits all the boundaries and outlines the numbers, ranks and duties of the officers, and the second section which involves the procedures for making changes in the city boundaries as defined in chapter 222 (ORS, Vol. 2, 431), allowing for mergers (annexation) and for consolidation of both adjoining and non-adjoining territories for proper functioning of the city.

Thus, by Oregon state law Tri-Met is a municipal corporation which can exercise public powers with a taxing right and having a mandate to use its taxes to provide adequate and convenient transportation services to the people of the Portland metropolitan area.

One significant condition imposed on Tri-Met was that the corporation was limited by law regarding the amount of money or proportion of its total budgetary expenses that may be collected from passengers. The bus fares should cover only one-third of the costs while the other two-thirds is to come from payroll tax of employers of the three counties.

On the formation of Tri-Met, RCTC properties acquired by the Portland Mass Transit Advisory Commission were transferred to the 
new entity. With all the financial and physical infrastructural support assured, Tri-Met had two major steps to take to assure proper functional activity and satisfactory service to customers. Firstly, it had to negotiate and conclude a contract (favorable to both the corporation and the workers) with the transit workers union which would bring their pay scale to a status comparable with that of other transit workers on the West Coast. The second major requirement was to hold open public hearings to consider ways and means of raising the revenue necessary to maintain a publicly owned transit system such as this, without charging high fares.

With several taxing options available to it, Tri-Met adopted a payroll tax effective 1970. The payroll tax was equivalent to $0.5 \%$, and was levied on 38,000 employees in the tri-county area. The bulk of the monies collected from this came from Multnomah (77\%), while from Washington and Clackamas counties $13 \%$ and $10 \%$ respectively were obtained (Table 1). By adopting these taxing measures and also by demonstrating its ability to pay a share of the total operational costs, Tri-Met qualified itself to receive a federal grant from the Urban Mass Transportation Administration (UMTA) of the U.S. Department of Transportation. This grant pays for $80 \%$ of the cost of capital items such as buses, passenger shelters, and special projects such as the Lift. The federal government also provides approximately five million dollars a year as operating subsidy. 
Having succeeded in providing the labor union employees with fair wage rates, Tri-Met was able to abate all strikes and curb work disruptions, assuring a continuous labor output. The bus fare charges were successfully held at a maximum acceptable limit and at the same time the corporation sought federal matching funds to acquire new and pollution-free buses, and for the first time in several years transit buses started running on time with little or no doubt in the minds of passengers about the reliability of the service. Such preliminary success in administrative and financial management, especially the better and assured methods of raising revenue, placed Tri-Met in good stead in the successful and continued execution of their transport operations.

Administration, Machinery and Operations

Although state-created, Tri-Met is not directly under the jurisdiction of the state Governor. Rather, it is controlled by a seven-member Board of Directors appointed by the Governor to a four year term of office. This board appoints the General Manager as the administrative head who is accountable and reports to it. The lower tiers of the hierarchy comprise professional and administrative heads and workers in five different departments: Finance, Marketing, Operations, Planning and Development, and Public Affairs. The current driver force is 900 out of total employee roster of 1341 , 
which makes the corporation the 25th largest employer in the Port1and Metropolitan Area. Tri-Met's entire vehicular force during early 1979, totaled 555 buses, 15 mini-buses (the Lift), and a fleet of other vans and cars for pooling. The buses ply on 71 routes and cover 20.2 million miles annually (Tri-Met, 1979d, 44).

Bus ridership and consequently the number of vehicles in use at different times of the day vary between peak and off-peak hours. Peak periods occur between $6.30 \mathrm{a} . \mathrm{m}$. and $9.00 \mathrm{a} . \mathrm{m}$. and between 4.00 p.m. and 6.30 p.m. These periods coincide with times when most people travel to work or school in the morning and return home in the evening.

TABLE I

A COMPARISON OF FINANCES, SERVICES AND PASSENGERS FROM THE THREE COUNTIES

\begin{tabular}{lcccc}
\hline County & $\begin{array}{l}\text { Service } \\
\text { Population }\end{array}$ & $\begin{array}{c}\text { Payroll } \\
\text { Tax }\end{array}$ & $\begin{array}{l}\text { Weekday } \\
\text { Passengers } \\
\%\end{array}$ & $\begin{array}{l}\text { Total } \\
\text { Bus } \\
\text { Miles } \\
\%\end{array}$ \\
\hline Multnomah & 53 & 77 & 77 & 64 \\
Clackamas & 22 & 10 & 8 & 16 \\
Washington & 20 & 13 & 15 & 20 \\
Total & 100 & 100 & 100 & 100 \\
\hline
\end{tabular}

Source: "Tri-Met Fact Sheet," 1979d, p. 2. 
In January 1979, during the two peak periods, 475 buses operated in the morning and 421 in the evening respectively. During off-peak hours only 224 buses (less than half of the morning peak) are in service. Buses operate with in 5-25 minute headway in peak periods but this falls to 15-60 minutes in off-peak times, sometimes even less in sparsely populated areas.

Annual ridership of Tri-Met buses increased by $11 \%$ from fiscal year 1978 to 1979. From the fares, revenue for the same year was higher than preceeding years by $19 \%$, indicating that average daily ridership had reached $55 \%$ of the target goals of the 5-year transportation plan. At present (1979) $4 \%$ of all trips made in the service region are made with a Tri-Met bus and $96 \%$ by the private car or other modes. In downtown Portland however, $36 \%$ of all trips made within the CBD are made by Tri-Met transit. Passenger counts indicate that nearly al1 age groups are served. A summary of these results show that $4 \%$ and $10 \%$ of the ridership comprises of grade school and high school children respectively. The majority of riders (74\%) are adults, while senior citizens and disabled people make up $12 \%$. Fares vary for these riders in different routes as shown on table 2 .

In the area of planning, a high degree of co-operation has existed between the City of Portland and Tri-Met, in changing the city structure for easy transportation. One such significant change was the creation by Tri-Met of the downtown Portland Mall. This development, $80 \%$ of which was subsidized by Federal (UMTA) funds, is an innovative project representing a major commitment to public transit, the 
maintenance of clean air, and urban amenity. The Portland Mall is comprised of eleven blocks along S.W. Fifth and Sixth Avenues from West Burnside Street to S.W. Madison Street. It serves as the central axis of mass transit in the CBD, tripling the people-carrying capacity of the two streets by separating auto, bus, and pedestrian traffic. In some places along the two avenues, traffic is restricted to buses only. In the mall are eight kiosks for planning trips by bus in the region and 35 passenger shelters featuring seats and maps. Each shelter has a television screen showing bus arrival and departure times and a direct phone line to the information center of Tri-Met.

TABLE II

BUS FARE CATEGORIES

\begin{tabular}{|c|c|}
\hline Rider & Fare $(\$)$ \\
\hline 1 Grade school children & 0.30 \\
\hline 2 High school students (with ID) & 0.30 \\
\hline 3 Senior citizens (off-peak) & $\begin{array}{l}0.10 \text { (Free at } \\
\text { nights after } \\
7.00 \mathrm{p} \mathrm{m.} \mathrm{and} \\
\text { on weekends) }\end{array}$ \\
\hline 4 Adults (a) Zone II & $\begin{array}{l}0.45 \text { (Pass } \\
\$ 16 / \text { month) }\end{array}$ \\
\hline (D) Zone III & $\begin{array}{l}0.65 \text { (Pass } \\
\$ 20 / \text { month) }\end{array}$ \\
\hline (c) Vancouver/Portland & $\begin{array}{l}0.75 \text { (Pass } \\
\$ 27 / \text { month) }\end{array}$ \\
\hline
\end{tabular}

Source: "Tri-Met Fact Sheet," 1979d, p. 3. 


\section{Transportation Zoning}

Three zones have been delimited to correspond with three fare levels for adult passengers in the service region. These are:

(1) Zone I (Fareless Square) - A 288 square block fare-free area, bounded on the north by N.W. Hoyt Street, east by the Willamette River, and the south and southwest by the freeways. It includes all of the Portland CBD and Portland State University as well as all of the Portiand Student Services student houses except the Goose Hollow which is three blocks beyond the western edge of the zone. The creation of Fareless Square serves as an incentive for increased interaction while at the same time reducing traffic congestion in the city center. The convenience of changing buses is suitably enhanced by the presence of the Portland Mall in the square. Students of Portland State University travelling by bus from distant areas of the city also change buses at the downtown mall.

(2) Zone II - All of the area outside of Fareless Square but within the City of Portland comprise the second zone. Adult riders pay a fare of $\$ 0.45$ for riding in this region. Students with identity cards and senior citizens may ride in this zone at reduced fare. Zone II comprises the bulk of the residential areas in Portland and most students in Portland State conceivaby reside here. (3) Zone III - Zone three comprises of the service area outside of the City of Portland. Included in this category are all of the suburban communities, even as remote as Estacada, Canby, Wilsonville, 
Sherwood and Forest Grove. Riders to/from these areas are charged a fare of $\$ 0.65$ per trip, while those from Vancouver, Washington pay $\$ 0.75$ per trip respectively.

\section{Other Services}

Since 1976, regional employers, including commercial, recreational, educational and community organizations were informed of Tri-Met's ancillary transport services available to them as commuter options. These include:

(a) Carpool: Three or more riders from the same or nearby neighborhoods who agree to share the gas and other expenses may use Tri-Met's carpool facilities to any place at any time. Tri-Met provides free matching information to people in the same neighborhood and working in the same area. Workers who carpool every day to work in downtown Portland are provided with a parking permit as an incentive by Tri-Met and the City of Portland, enabling them to park at any downtown six-hour meter all day for $\$ 15$ a month. Carpoolers may also use any of the 63 park-and-ride lots in the tri-county area. In 1976, the information center responded to over 15,000 telephone calls on carpoo1, and 1,300 applications for the service were received. In a recent survey of the tri-county service region, 19\% of the residents were found to carpool 3 to 5 days per week with $9 \%$ participating 5 days or more a week.

(b) Buspool: This is a special express bus service to transport 
people who may be starting work either earlier or later than the normal morning peak when more buses are available. Riders are picked up from their neighborhoods or local parking lots and then taken via the shortest route to the work site. Buspools are generally initiated by large employers who contact the corporation for help in providing the employees with transportation facilities. (c) Vanpool: Like carpool, vanpool may be used by people who wish to share the running costs of the van. Some employees may contact the corporation and get 8 to 12 people assigned to one van, with one. person assuming driver-responsibilities. Vanpool facilities have been used quite frequently by students on field trips. (d) Honored Citizens Program: This program provides free transit services for the elderly and disabled in the evenings and on weekends. During off-peak hours they are charged a reduced fare of $\$ 0.10$ a trip. During peak hours, however, they may be required to pay the full fare, depending on the mood of the driver.

\section{Demand-Responsive Services}

As a condition for running a metropolitan transport service, TriMet is required to provide transportation facilities for physically or otherwise handicapped people in a program called the "Lift." It comprises of a fleet of 15 specially equipped mini-buses which provide convenient door to door service to passengers. In the past taxi cabs have been hired by Tri-Met to transport handicapped people as a supplementary part of the "Lift" program. In either case, the times when riders 
are picked up at home and then at school may be specific for the different riders. In many cases, only one passenger is transported at a time, either from home to school or vice versa. DRS services are financed mostly by special grants from state and local governments and agencies, a percentage of which the users pay.

The 'Lift' service transports about 350 people a day, $20 \%$ of whom are on wheel chairs. About $80 \%$ of 'Lift' passengers are medically oriented while $7-10 \%$ travel to schools and colleges. Those travelling to colleges comprise only about $3 \%$ of the total.

Tri-Met's Long Range Objectives

One full Tri-Met bus could replace up to thirty-five cars and thus free as many parking spaces. In a month, Tri-Met riders would have saved 1 million gallons of fuel. In one year, bus riders save enough fuel energy capable of supplying heat to all Portland homes for more than 2 months. With these potentialities in mind as well as the responsibility of the corporation to solve the region's transportation problems by 1990 , the Board of Directors established five major objectives in 1977. These are:

(1) To achieve a major increase in ridership and so minimize the transportation, energy and pollution problems of the region by 1990 .

(2) To provide superior, dependable public transportation for residents of the tri-county area, making it sufficiently attractive especially to those people now using private 
automobiles.

(3) To provide new transit services in suburban areas, featuring a system of satellite bus stations with auto parking facilities so that riders may leave their cars at these stations, board express buses to other satellite stations or to down town Portland terminals. Each station may also be served by a local bus network to take riders to their ultimate destinations.

(4) To relieve traffic congestion on existing freeways, arterials and city streets.

(5) To help control air pollution in the metropolitan area especially by purchasing buses equipped with devices for reducing the volume of pollution.

To cope with these objective as well as the increasing demand, two developments are being planned by the corporation. The first is the acquisition by Tri-Met of articulated buses which carry one and a half times as many passengers as the ones currently in use.? They may thus prove to be more gas efficient in this time of high fuel costs. It is felt that articulated buses cope with peak hour demand more effectively than ordinary buses, whereas their operation costs in so far as fuel and labor are concerned are about the same as for conventional buses while carrying more people.

The capacity of the present Tri-Met buses is approximately 48 seated and 30 standing. An articulated bus on the other hand is essentially two coaches steered by one operator and having a capacity of about 67 seated and 50 standing. 
The second major proposal calls for the construction of a light rail transit line from the Portland Mall to Gresham. This would constitute a historical reversal indicating the possible role which a fixed-rail system might again play in public transit in the Portland metropolitan area.

Isolating PSU students as a market segment for the purpose of this study, the extent to which the public transit services outlined above compare favorably with other modes in so far as transportation to school is concerned is investigated in the survey and analys is of the next chapter. 
CHAPTER IV

\section{STUDENT TRANSPORTATION SURVEY AND ANALYSIS}

A survey was conducted during the middle of Fall quarter, 1979 among students taking courses in the Department of Geography at Portland State University. 1 A total of 510 questionnaires was handed out. After the survey, 443 questionnaires were returned, of which 377 had been completed. Sixteen were rejected on the basis of unclarity, dubious information, or incompleteness, leaving 361 (2.14\% of the total PSU student population) which were analyzed as the sample.

The Sample

The reliability of any survey data depends upon the representativeness of the sample selected. In this study, majors in the different disciplines of the schools and colleges of the university were represented in various proportions. Although the Department of Geography was used as the venue, majors in this discipline comprised only $15.3 \%$ of the sample, as compared with Business Administration (15.2\%) and Science $(10.7 \%)$. The College of Social Science as a whole accounted for over one-third, while Arts and Letters, Education and Urban Affairs constituted respectively $8.1 \%, 7.8 \%$ and $3.3 \%$ of respondents. Students

The survey period was 0ctober 12-19, 1979. Most of the questionnaires were completed during this period. A few classes which had mid-term tests during this period were requested to complete them in the following week. 
majoring in General Studies and those who were yet to decide on a major together constituted $16.4 \%$ of the sample (Table III).

\section{Content of Survey Questionnaire}

To ensure a good sample return the questionnaire was limited to five pages (see Appendix) containing questions aimed at testing the hypotheses postulated earlier in the study. Questions were asked on the location of students' dwelling units (DU's), occupancy of DU in terms of number of persons and duration of residence and distance from school. School-related questions included course load, time of day when the student is usually at school, relationships (if any) between job and school, and how all these different parameters affect modechoice. The questions on mode focussed on the major considerations that affect the choice of the particular mode most frequently used by the student. These considerations included time taken to travel to school, availability and frequency of public transport, and income level of the student. The final section of the questionnaire requested other comments or suggestions which the respondent might care to make regarding transportation to school.

The informal parts of the study were done through an internship of the author with Tri-Met for one quarter, during which period the respective information was acquired by directly interviewing personnel of the relevant departments. The PSU parking office and the PSU Center for Population Studies also provided relevant information for the study. 
TABLE III

DISTRIBUTION OF THE SAMPLE AMONG MAJORS OF VARIOUS

SCHOOLS AND COLLEGES OF THE UNIVERSITY

Major

$\%$

Major

$\%$

Social Science

Geography

Public Administration

General Social Science 4.4

History

3.9

Sociology

2.5

Psychology

2.2

Economics

Political Science

Anthropology

Business Administration

Science

Engineering

Biology

Earth Sciences

Chemistry

1.9

1.9

1.1

3.3

2.2

1.9

1.1
37.7 Science (continued)

Mathematics $\quad 1.1$

Physics

1.1

Arts and Letters

8.1 Languages (English, French, German, Russian)

2.8

Speech Communication 2.2

Art and Architecture $\quad 1.7$

Philosophy

1.4

15.2 Education

7.8

10.7 Urban Affairs

3.3

Health and Physical Education

0.8
General Studies/ Undecided Majors
16.4 
Survey Results

The results of the survey are discussed, with tabulations, in the following sub-sections. Total population of the City of Portland and the student population of PSU are related in Tables IV, V, VI and VII in the first sub-section, which discusses student distribution. Relationships between mode and cost of transportation are shown in Tables VIII, IX and X. Nature of employment, income level, and distance are illustrated in Tables XI, XII and XII. The remaining data (Tables XIV to XVII) pertain to the statistical analysis and prediction results.

The Distribution of PSU Students in Portiand

There are wide differences in the density and distribution of population in the various sections of Portiand. Some of the factors accounting for these differences are, among others, variation in cost of housing, differences in income levels, and location preference. of these, differences in income and therefore in the ability to afford more expensive and spacious housing contribute more to the differences in density and distribution of population than the other factors.

In high income areas both student and total population densities are likely to be different from those in low income areas. High income areas may have low population densities while at the same time having many more students than low income areas. Therefore, in attempting to determine relative distribution of students in different areas, the notion of density or more specifically area should play a secondary 
role. Rather the proportion of students may be directly related with the resident population of each region separately.

The population estimate for the City of Portland was obtained from the 1980 population projections of all the census tracts of each of the major sections of the city (Figure 2). ${ }^{2}$ These figures are shown in Table IV.

TABLE IV

POPULATION OF THE CITY OF PORTLAND BY SECTION (I980 ESTIMATE)

\begin{tabular}{lcc}
\hline Section & Population & $\%$ \\
\hline Southeast & 129,252 & 33.6 \\
Northeast & 108,170 & 28.1 \\
Southwest & 69,302 & 18.0 \\
North & 65,024 & 16.9 \\
Northwest & 13,013 & 3.4 \\
Portland & 384,761 & 100.0 \\
\hline
\end{tabular}

During Fall quarter 1979, the total number of registered students at PSU was 16,841 . This represents a $12 \%$ increase over the enrollment for Fall 1975 (Table V), indicating a growing problem

${ }^{2}$ Census tract data were obtained from the PSU Center for Population Studies. Populations of the tracts constituting each region were added separately. 


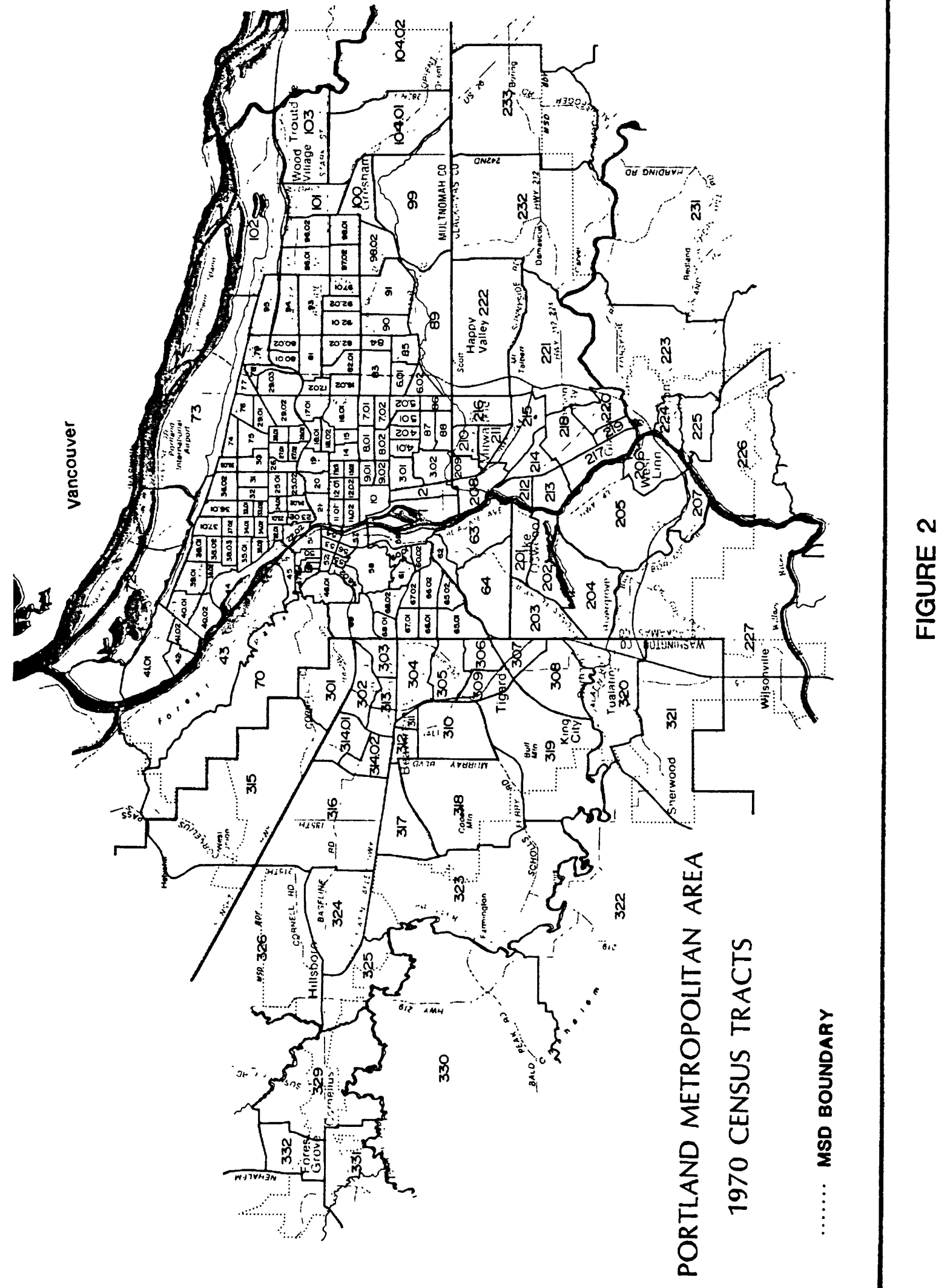


of student commuting to school with reference to seriously limited parking space.

The sample returns $(n=361)$, represent $2.14 \%$ of the 1979 Fall quarter enroliment of 16,841 students. The percentages of the sample and the corresponding numbers of students from each section of Portland, using Fall 1979 as base figure, are shown in Table IV. Nearly two-fifths of the students reside in Southwest and one-quarter in Southeast, with relatively fewer students living in other sections of the city (Figure 3 ).

TABLE V

CHANGES IN STUDENT ENROLLMENT IN PSU SINCE 1975

\begin{tabular}{ccc}
\hline Fal1 Quarter & $\begin{array}{l}\text { Student } \\
\text { Population }\end{array}$ & $\begin{array}{c}\% \text { Increase } \\
\text { over 1975 }\end{array}$ \\
\hline 1975 & 15,038 & - \\
1976 & 15,070 & 0.21 \\
1977 & 15,888 & 5.70 \\
1978 & 15,924 & 5.90 \\
1979 & 16,841 & 11.99 \\
\hline
\end{tabular}

From the population and enrollment figures, a concentration coefficient was calculated for each region by dividing the percentage of students from each section (Table VI) by the corresponding percentage population (1980 estimate, Table IV). These results are shown in Table VII. 

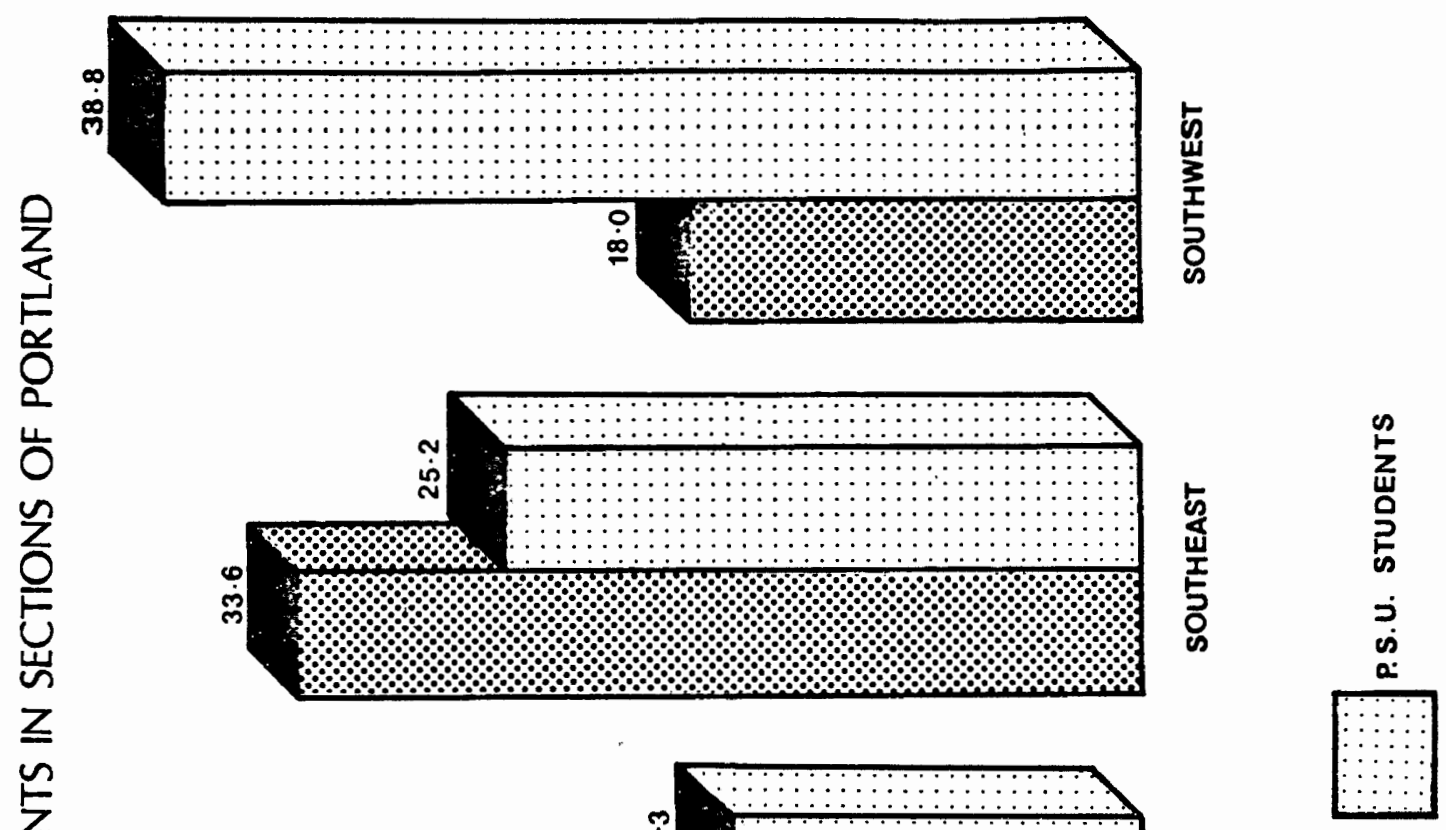

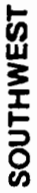

Z

$\frac{n}{5}$

栗

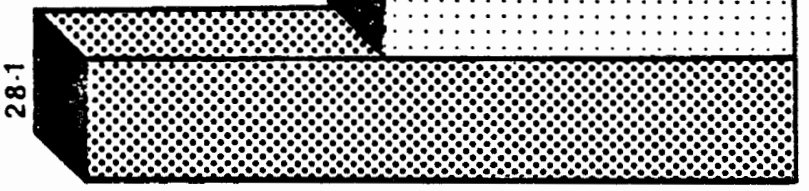

$\frac{5}{5}$
$\underline{\underline{T}}$
$\frac{1}{10}$
$\frac{0}{2}$
2

$m$

峁

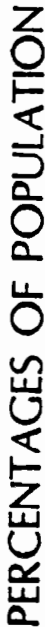

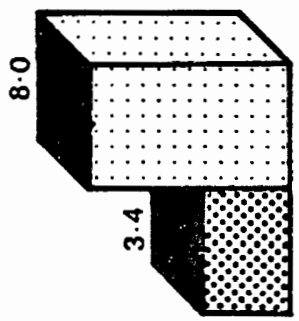

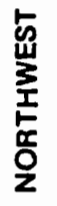

을
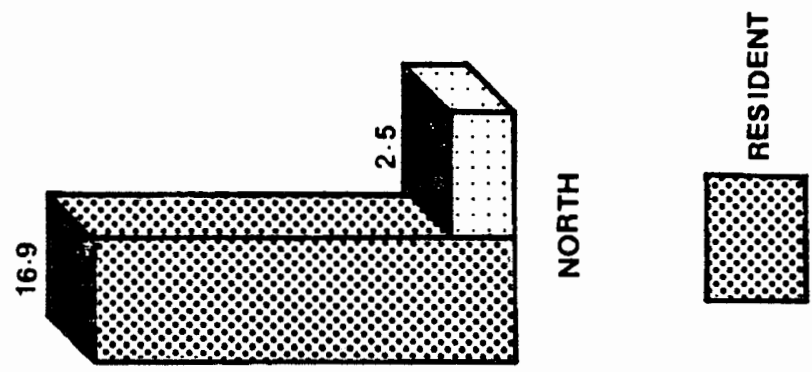
A coefficient of 1.00 would signify a normal situation where the number of students from a section is proportional to the total population of the section. A higher coefficient means that there is a higher than proportionate number of students, whereas a lower coefficient indicates a section with a comparatively lower than proportional number of students. From the coefficients it can be seen that North, Northeast and Southeast respectively have lower than average proportions of students attending Portland State. On the other hand, both Northwest and Southwest have over twice the expected proportion of students.

TABLE VI

NUMBERS OF STUDENTS ATTENDING PSU FROM SECTIONS OF PORTLAND AS ESTIMATED FROM THE SAMPLE

\begin{tabular}{ccc}
\hline Section & $\begin{array}{l}\text { Estimated } \\
\text { Number of } \\
\text { Students }\end{array}$ & Percentage \\
\hline N & 421 & 2.5 \\
NW & 1,347 & 8.0 \\
NE & 2,745 & 16.3 \\
SE & 4,244 & 25.2 \\
SW & 6,534 & 38.8 \\
Others * & 1,550 & 9.2 \\
\hline
\end{tabular}

*Students living outside Portland. 


\section{TABLE VII}

CALCULATED CONCENTRATION COEFFICIENTS OF STUDENTS IN SECTIONS OF PORTLAND

\begin{tabular}{cc}
\hline Section & $\begin{array}{l}\text { Concentration } \\
\text { Coefficient }\end{array}$ \\
\hline$N$ & 0.15 \\
NE & 0.58 \\
SE & 0.75 \\
SW & 2.16 \\
NW & 2.35 \\
\hline
\end{tabular}

Relative Use of Different Modes

The proportions of users of different transport modes are shown in Table VIII and Figure 4. There are about as many riders of the public bus as there are users of the private car. These two modes together account for $82 \%$ of users. About $10.5 \%$ of the students interviewed walk to school, $4.2 \%$ ride bicycles and $1.1 \%$ ride motor cycles.

Cost of Transportation and Mode

The cost associated with each mode and the respective mean distance covered by the sampled students are presented in Table IX. With the exception of walking, which actually involves no monetary cost, and the bicycle, whose maintenance costs are very little, the 


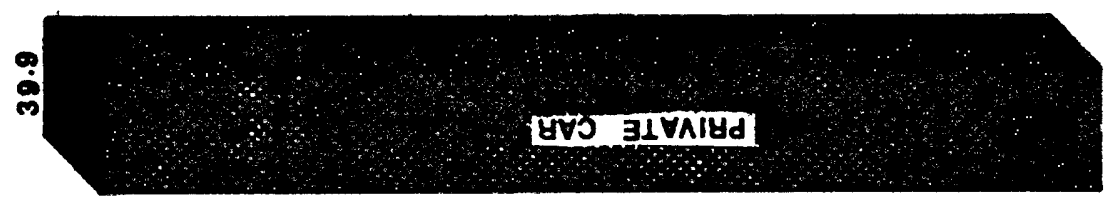

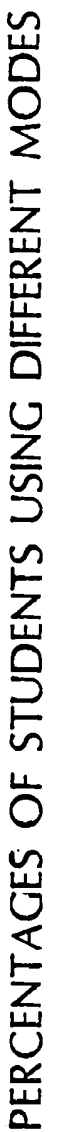
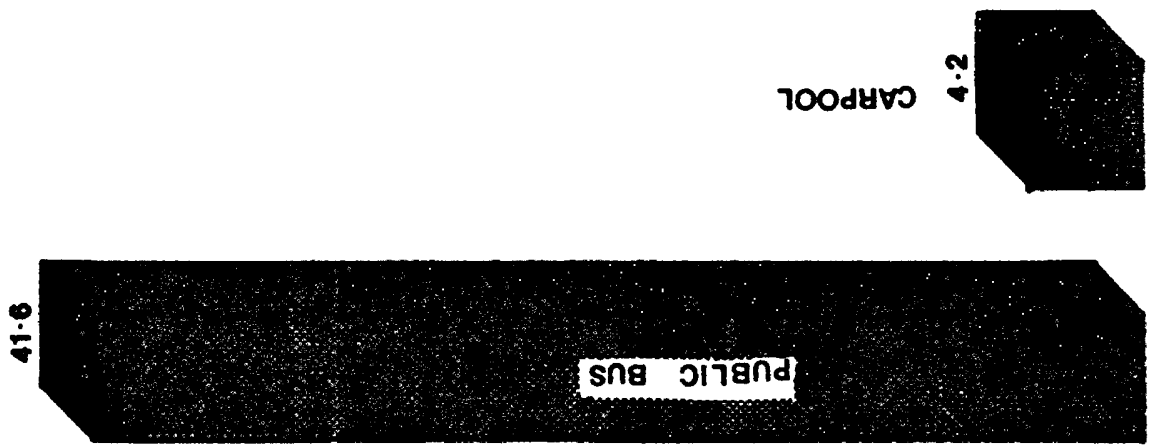

$+$

$\frac{u}{\frac{\pi}{5}}$
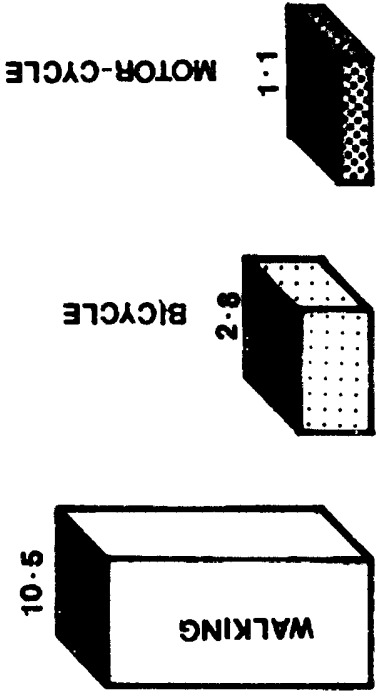


\section{TABLE VIII}

RELATIVE USE OF TRANSPORT MODES

\begin{tabular}{ccc}
\hline $\begin{array}{l}\text { Mode Most } \\
\text { Frequently Used }\end{array}$ & $\begin{array}{l}\text { Number } \\
\text { of Users }\end{array}$ & Percentage \\
\hline Tri-Met Bus & 150 & 41.6 \\
Private Car & 144 & 39.9 \\
Walking & 38 & 10.5 \\
Carpool & 15 & 4.2 \\
Bicycle & 10 & 2.8 \\
Motorcycle & 4 & 1.1 \\
\hline
\end{tabular}

cheapest means of transport for students is the public bus with a net expense of seven cents per mile for October 1979. The next cheapest was carpool averaging about ten cents per mile. The motorcycle and private car cost respectively 15 and 27 cents per mile.

Cost of Transportation and Distance

Grouping of the data on transportation cost regardless of mode (Table $X$ ) reveals that for distances less than ten miles, little relationship exists between transport cost and distance. In fact over half of the students reside within a ten-mile radius of the school, paying mostly forty-five cents or less: Above the trip cost of $\$ 1.00$ however, there is a direct linear relationship between transportation cost and distance (Figure 5). 
TABLE IX

RELATIVE COSTS OF TRANSPORT MODES

\begin{tabular}{llcl}
\hline Mode & $\begin{array}{l}\text { Cost Per } \\
\text { Trip (\$) } \\
\text { (One Way) }\end{array}$ & $\begin{array}{l}\text { Mean Distance } \\
\text { in Miles (One } \\
\text { Way) }\end{array}$ & $\begin{array}{c}\text { Cost Per } \\
\text { Mile (\$) }\end{array}$ \\
\hline Private Car & 2.66 & 9.9 & 0.27 \\
Motorcycle & 0.89 & 5.8 & 0.15 \\
Carpool & 0.65 & 6.5 & 0.10 \\
Tri-Met Bus & 0.54 & 7.5 & 0.07 \\
Bicycle & 0.47 & 3.9 & 0.12 \\
Walking & 0.00 & 1.2 & 0.00 \\
\hline
\end{tabular}

TABLE $X$

MEAN DISTANCE AND COST OF ONE-WAY TRANSPORTATION (INCLUDING DAILY PARKING)

\begin{tabular}{lcrrrr}
$\begin{array}{l}\text { Cost of Trans- } \\
\text { portation (\$) }\end{array}$ & $\begin{array}{l}\text { Number of } \\
\text { Riders }\end{array}$ & $\begin{array}{l}\text { Mean Distance } \\
\text { (Miles) }\end{array}$ & $\begin{array}{l}\text { Time } \\
\text { (Minutes) }\end{array}$ & $\begin{array}{l}\text { Minutes } \\
\text { Per Mile }\end{array}$ \\
\hline $0.00-0.45$ & 137 & 38.0 & 4.06 & 22.3 & 5.4 \\
$0.46-1.00$ & 73 & 20.2 & 9.93 & 39.5 & 3.9 \\
$1.01-1.50$ & 34 & 9.4 & 4.09 & 13.0 & 3.1 \\
1.51 .2 .00 & 16 & 4.4 & 5.81 & 17.0 & 2.9 \\
$2.01-3.50$ & 52 & 14.8 & 7.70 & 24.8 & 3.2 \\
$3.51-5.00$ & 41 & 11.0 & 10.70 & 38.3 & 3.5 \\
$5.00+$ & 8 & 2.2 & 31.19 & 61.7 & 1.9
\end{tabular}




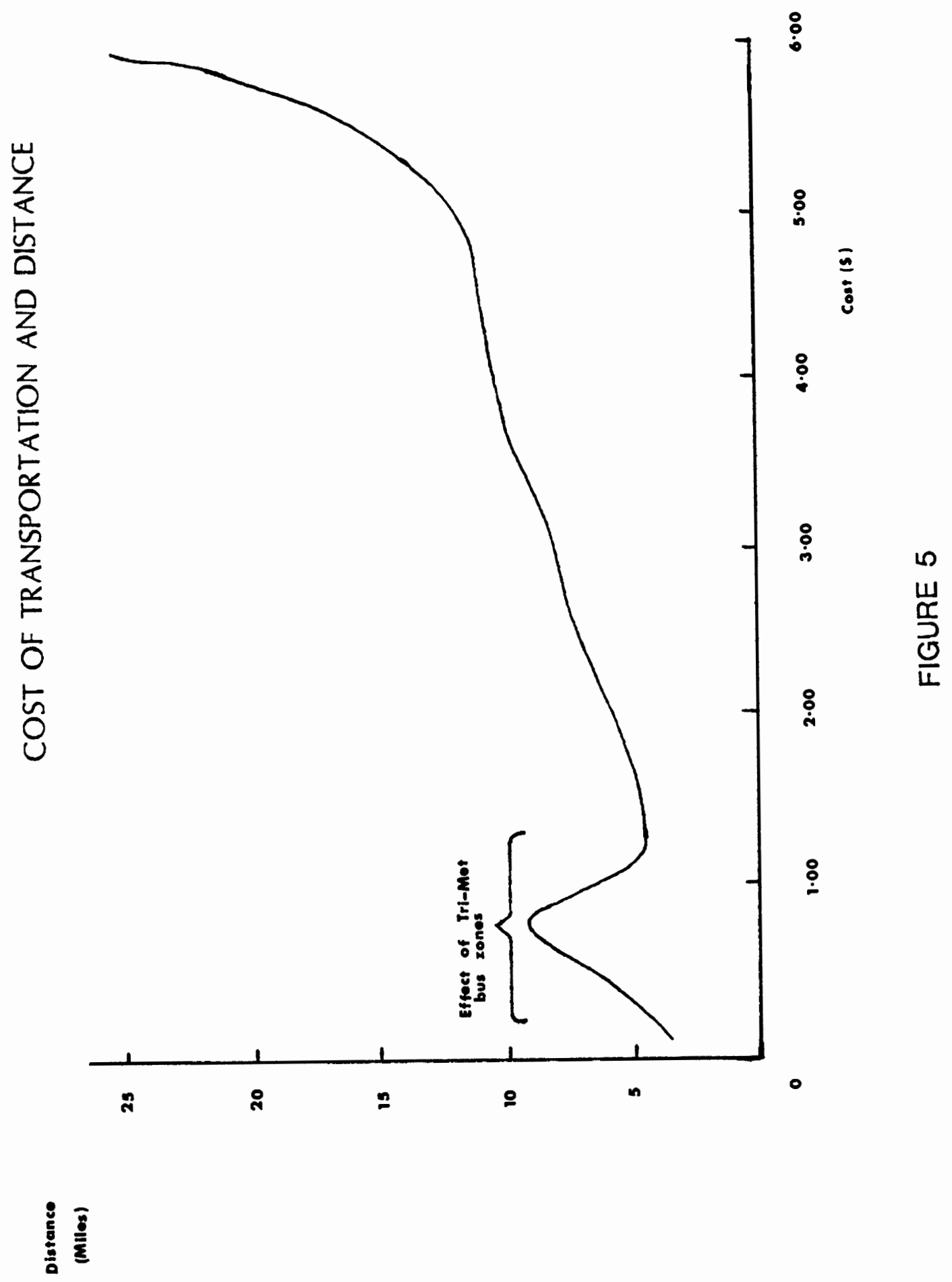


Cost of Transportation and Time

Most of the students who took part in the survey arrived at school within twenty to thirty minutes after leaving home. There was no indication of a disadvantage in time in the use of the public bus. In comparison to other modes however, the public bus was slightly slower. Apart from that mode, the relationship between cost and mode was generally positive (Figure 6 ). On the other hand time taken per unit distance generally decreased with increasing transportation cost ( Table $x$ ), irrespective of the mode.

\section{Employment and Income}

With regard to employment, over half $(51.5 \%)$ of the students interviewed had part-time employment, while over one-fifth (22.2\%) had full-time employment. Unemployed students were slightly over one-quarter $(26.3 \%)$ of the interviewed students .

In addition to the high unemployed percentage, a total of $35.5 \%$ earn less than $\$ 5,000$ a year. In other categories, $5.8 \%$ earn between $\$ 10,000$ and $\$ 12,500$, while up to $11.0 \%$ receive incomes over $\$ 12,500$ (Table XI).

Location of Residence and Income

With respect to distribution, the Southwest and Southeast sections had consistently high proportions in all income groups. More significant is that in the high income group, out of the $26.3 \%$ earning over $\$ 7,5000,17.0 \%$ are from either Southeast or Southwest. While 
56

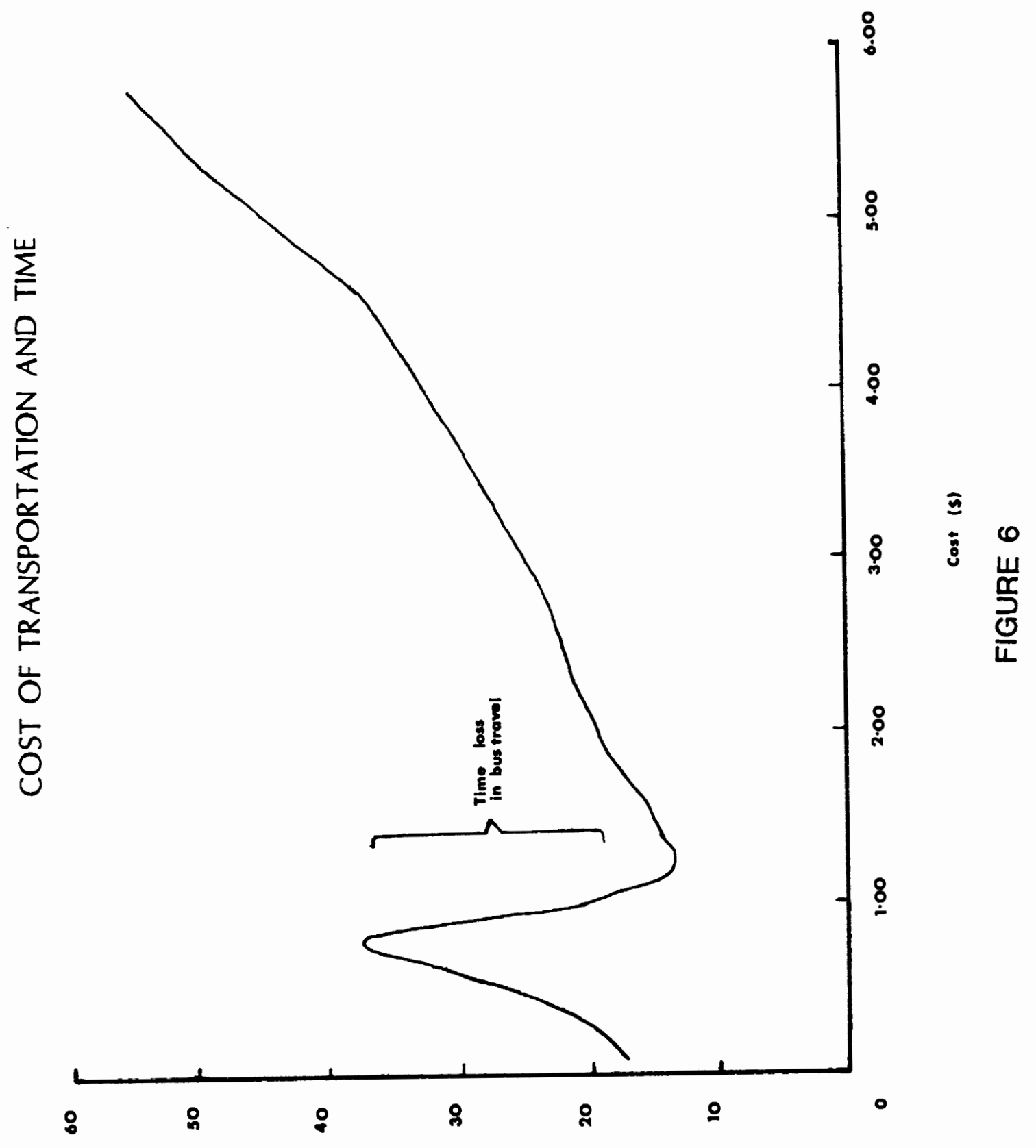

II 
TABLE XI

INCOME VERSUS LOCATION OF RESIDENCE

Income Group

N NE NW

SE

SW Others

Total

\begin{tabular}{|c|c|c|c|c|c|c|c|}
\hline 1. $\$ 0.00$ & $\left(7^{4} .1\right)^{*}$ & $\begin{array}{c}16 \\
(4.4)\end{array}$ & $(2.2)$ & $\begin{array}{c}23 \\
(6.4)\end{array}$ & $\begin{array}{c}34 \\
(9.4)\end{array}$ & $\begin{array}{c}10 \\
(2.8)\end{array}$ & $\begin{array}{c}95 \\
(26.3)\end{array}$ \\
\hline 2. $\$ 1-2,499$ & $\left(\begin{array}{c}1 \\
(0.3)\end{array}\right.$ & $\begin{array}{c}10 \\
(2.8)\end{array}$ & $\left(7^{5} .4\right)$ & $\begin{array}{c}16 \\
(4.4)\end{array}$ & $\begin{array}{c}25 \\
(6.9)\end{array}$ & $(1.4)$ & $\begin{array}{r}62 \\
(17.2)\end{array}$ \\
\hline 3. $\$ 2,500-4,999$ & $\left(0^{2} .6\right)$ & $\begin{array}{c}9 \\
(2.5)\end{array}$ & $\begin{array}{c}7 \\
(1.9)\end{array}$ & $\begin{array}{c}11 \\
(3.1)\end{array}$ & $\begin{array}{c}31 \\
(8.6)\end{array}$ & $\begin{array}{c}6 \\
(1.7)\end{array}$ & $\begin{array}{c}66 \\
(18.3)\end{array}$ \\
\hline 4. $\$ 5,000-7,499$ & $\begin{array}{c}0 \\
(0.0)\end{array}$ & $\begin{array}{c}8 \\
(2.2)\end{array}$ & $(0.3)$ & $\begin{array}{c}9 \\
(2.5)\end{array}$ & $\begin{array}{c}21 \\
(5.8)\end{array}$ & $(1.1)$ & $\begin{array}{r}43 \\
(11.9)\end{array}$ \\
\hline 5. $\$ 7,500-9,999$ & $\begin{array}{c}0 \\
(0.0)\end{array}$ & $\begin{array}{c}7 \\
(1.9)\end{array}$ & $(1.1)$ & $\begin{array}{c}12 \\
(3.3)\end{array}$ & $\begin{array}{c}9 \\
(2.5)\end{array}$ & $(0.3)$ & $\begin{array}{c}33 \\
(9.1)\end{array}$ \\
\hline 6. $\$ 10,000-12,499$ & $\begin{array}{c}0 \\
(0.0\end{array}$ & $\left(0^{2} .6\right)$ & $c^{1}$ & $\begin{array}{c}5 \\
(1.4)\end{array}$ & $\begin{array}{c}9 \\
(2.5)\end{array}$ & $\left(1^{4} .1\right)$ & $\begin{array}{c}27 \\
(5.8)\end{array}$ \\
\hline 7. $\$ 12,500+$ & $\left(0^{2} .6\right)$ & $\begin{array}{c}7 \\
(1.9)\end{array}$ & $\left(0^{3} .8\right)$ & $\begin{array}{c}15 \\
(4.2)\end{array}$ & $\left(\begin{array}{c}11 \\
(3.1)\end{array}\right.$ & $\left(0^{3} .8\right)$ & $\begin{array}{r}41 \\
(11.4)\end{array}$ \\
\hline Total & $\begin{array}{c}9 \\
(2.5)\end{array}$ & $\begin{array}{c}59 \\
(16.3)\end{array}$ & $\begin{array}{c}29 \\
(8.0)\end{array}$ & $\begin{array}{c}91 \\
(25.2)\end{array}$ & $\begin{array}{c}140 \\
(38.8)\end{array}$ & $\begin{array}{c}33 \\
(9.2)\end{array}$ & $\begin{array}{c}361 \\
(100.0)\end{array}$ \\
\hline
\end{tabular}

* Figures in brackets indicate percentages.

Northeast and Northwest had moderate distributions in all income group, North Portland had representatives clustered in the low income groups (Table XI).

With the exception of North Portland, the proportion of parttime students from each of the major sections is greater than either full-time or unemployed students (Table XII). In addition, there are proportionally more employed living in 
TABLE XII

EMPLOYMENT VERSUS RESIDENTIAL LOCATION

\begin{tabular}{|c|c|c|c|c|}
\hline Location & $\begin{array}{l}\text { Not } \\
\text { Employed }\end{array}$ & $\begin{array}{l}\text { Part-time } \\
\text { Employed }\end{array}$ & $\begin{array}{l}\text { FuTl-time } \\
\text { Employed }\end{array}$ & Total \\
\hline N & $(1.7)^{*}$ & $\begin{array}{c}3 \\
(0.8) \\
\end{array}$ & $\begin{array}{r}2 \\
(0.6) \\
\end{array}$ & $\begin{array}{r}9 \\
(2.5) \\
\end{array}$ \\
\hline$N E$ & $\begin{array}{r}16 \\
(4.4) \\
\end{array}$ & $\begin{array}{r}30 \\
(8.3) \\
\end{array}$ & $\begin{array}{c}13 \\
(3.6) \\
\end{array}$ & $\begin{array}{r}59 \\
(16.3) \\
\end{array}$ \\
\hline NW & $\begin{array}{r}8 \\
(2.2) \\
\end{array}$ & $\begin{array}{r}14 \\
(3.9) \\
\end{array}$ & $\begin{array}{c}7 \\
(1.9) \\
\end{array}$ & $\begin{array}{c}29 \\
(8.0) \\
\end{array}$ \\
\hline$S E$ & $\begin{array}{c}23 \\
(6.4) \\
\end{array}$ & $\begin{array}{r}42 \\
(17.6) \\
\end{array}$ & $\begin{array}{c}26 \\
(7.2) \\
\end{array}$ & $\begin{array}{r}91 \\
(25.2) \\
\end{array}$ \\
\hline SW & $\begin{array}{r}34 \\
(9.4) \\
\end{array}$ & $\begin{array}{r}79 \\
(21.9) \\
\end{array}$ & $\begin{array}{c}27 \\
(7.5)\end{array}$ & $\begin{array}{r}140 \\
(38.8) \\
\end{array}$ \\
\hline Others & $\begin{array}{c}10 \\
(2.8)\end{array}$ & $\begin{array}{c}18 \\
(5.0) \\
\end{array}$ & $\begin{array}{r}5 \\
(1.4) \\
\end{array}$ & $\begin{array}{r}33 \\
(9.2) \\
\end{array}$ \\
\hline Total & $\begin{array}{r}95 \\
(26.3) \\
\end{array}$ & $\begin{array}{r}186 \\
(57.5) \\
\end{array}$ & $\begin{array}{r}80 \\
(22.2) \\
\end{array}$ & $\begin{array}{c}361 \\
(100.0) \\
\end{array}$ \\
\hline
\end{tabular}

*Figures in brackets indicate percentages

Southeast and Southwest than in any other section of the city. Of the sampled students, $48.2 \%$ lived in either of these sections and had either ful1-time or part-time job engagements.

Distance from School and Income

The relationship between student income and distance from school is not clearly defined. In this study, students with about average 


$$
k_{i}
$$


TABLE XIII

INCOME VERSUS DISTANCE

\begin{tabular}{lc}
\hline Income Group & $\begin{array}{c}\text { Mean Distance } \\
\text { (Miles) }\end{array}$ \\
\hline 1. Less than $\$ 2,500$ & 7.6 \\
2. $\$ 2,500-4,999$ & 6.6 \\
3. $\$ 5,000-7,499$ & 17.5 \\
4. $\$ 7,500-9,999$ & 5.3 \\
5. $\$ 10,000-12,499$ & 8.0 \\
6. $\$ 12,500+$ & 8.5 \\
\hline
\end{tabular}

income lived farthest from school while those within the low and high income groups lived approximately the same distance and were much closer to school (Table XIII). This contrasts with some findings on workers whose income tended to be positively correlated with distance between home and work place.

Analysis of the Data

The following variables were used in the analysis of the data:

$Y_{1}=$ Cost of one way transportation to school, including cost of parking per day for cars, motorcycles and carpool.

$Y_{2}=$ Transport mode most frequently used to school.

$x_{1}=$ Total road distance (in miles) between home and school. 
$x_{2}=$ Total time (in minutes) to make a one way trip to school.

$x_{3}=$ Income group of students from either full-time or parttime employment, grants, fellowships or other emoluments.

$x_{4}=$ Number of occupants in dwelling unit where the student currently resides.

$x_{5}=$ Duration of occupancy of dwelling unit (in years).

$x_{6}=$ Duration of occupancy of dwelling unit while attending Portland State University.

$x_{7}=$ School load of courses (credit nours) taken during Fall quarter, 1979.

In relation to the mean values of these variables, as observed from the sample, the variables of time and course load had the smallest standard deviations. These had mean values of 7.76 and 13.01 respectively, while the standard deviations were respectively 1.80 and 1.50 . Distance and number of occupants living in the dwelling unit had higher standard deviations (2.44 and 2.79 respectively) relative to their mean values of 4.37 and 3.19 respectively.

Multiple Linear Regression

With the available data a relationship was sought between the variable $Y_{1}$ and the rest of the remaining variables in the form:

$$
Y=f(X)+C
$$

where $Y_{1}$ represents the $Y$-axis, $C$ is some constant and $f(X)$ denotes 
the combined effects of the explanatory variables. Multiple linear regression tecinninue was used to determine whether $Y$ could be predicted from the variables in the linear form:

$$
Y=B_{0}+B_{1} X_{1}+B_{2} X_{2}+\ldots \ldots \ldots+B_{n} X_{n}
$$

where the B's represent the respective coefficients, the $X$ 's the variables, and $n=8$. The results are presented in Table XIV.

Although the results are somewhat disappointing as shown by the low $R^{2}$ statistic, two basic conclusions can however be reached. Firstly, using the standardized regression coefficient, ${ }^{3}$ a relationship can be predicted between the dependent variable (cost) and the independent variables selected. Secondly, the signs are all as expected except for distance which one would have expected to be positively correlated with cost. However where cost per unit distance is computed, this will increase with decreasing distance from the school. Finally, there is a weak association between the criterion and the independent variables.

In general, considering the differences in student transportation options in an urban area such as this, the broad zones of the Tri-Met bus service which bear the same fare within the same zone

${ }^{3}$ Note that the standardized regression coefficient or beta weight $\left(B_{y x}\right)$ is equal to the regression coefficient $\left(B_{y x}\right)$ multiplied by the ratio of the standard deviations of $x$ and $y$; i.e., $B_{y x}\left(\frac{S x}{S y}\right)$ (Nie et al., 325). If the beta weight is used, then $B_{0}=0$. The advantage of the beta weight is that it is more appropriate especially where the units of the variables are different. 


\section{TABLE XIV}

MULTIPLE LINEAR REGRESSION: TRANSPORTATION

AND PARKING COST AGAINST ALL VARIABLES

\begin{tabular}{llllr}
\hline Distance & $\begin{array}{l}\text { Regression } \\
\text { Coefficient }\end{array}$ & $\begin{array}{l}\text { Standard } \\
\text { Regression } \\
\text { Coefficient }\end{array}$ & Simple & F ratio \\
\hline Distance & -0.02 & -0.21 & -0.20 & 9.16 \\
Time & 0.03 & 0.03 & 0.05 & 0.01 \\
Income & 0.48 & 0.40 & 0.37 & 55.44 \\
Number in DU & 0.08 & 0.12 & 0.01 & 1.61 \\
$\begin{array}{l}\text { Duration of DU } \\
\text { Occupancy }\end{array}$ & 0.03 & 0.26 & 0.25 & 11.73 \\
$\begin{array}{l}\text { DU Occupancy } \\
\text { While at PSU }\end{array}$ & -0.75 & -0.12 & -0.12 & 1.64 \\
School Load & 0.12 & 0.10 & 0.08 & 6.24 \\
Mode & 0.04 & 0.04 & 0.05 & 3.82 \\
Regression & 0.20 & - & - & - \\
\hline
\end{tabular}

irrespective of significant differences in distance from the city center, and the fact that all the correlation coefficients differ from zero, the assumption of the hypothesis that the dependent variable can be predicted from the variables used in the analys is is nonetheless supported.

The analys is could be further pursued with principal components analysis in an effort to determine principal factors to reduce the 
numerous variables in the regression equation. For the purpose of this study, however, the variables making the most significant contribution to the variability in the dependent variable (based on the level of significance of the F-ratios), will be selected and used in further analysis.

Discriminant Analysis

From table XIV, the variables $x_{1}, x_{3}, x_{5}, x_{7}$ and $x_{8}$ had statistically significant F-ratios. 4 In addition they also had relatively high beta weights and correlation coefficients. Based on these values, these variables were selected for use in a discriminant analysis ( $P A=2$ option) with the objective of distinguishing among the different transport modes, using the variable $\gamma_{2}$ as the dependent variable and the other five as the discriminating variables, which are expected to be weighted so as to linearly combine some variables in a certain fashion distinct from other combinations.

Mode was used as the dependent variable instead of cost on the basis that the two are very related as shown in Table IX. The modes were regrouped into three categories instead of the original six based on user cost per mile, cost of maintenance, travel convenience

${ }^{4}$ This study assumes, just like the assumptions of the F-statistic, that the dependent variable used in the regression analys is is normally distributed. In addition the $n$ 's for all the variables are equal $(n=361)$. Note that the critical level of $F$ at $P_{0.99}=2.51$ at 8 and 352 degrees of freedom, corresponding respectively to the regression and error degrees of freedom. 
TABLE XV

RELATIVE POWER OF DISCRIMINANT FUNCTIONS FOR MODE CHOICE

\begin{tabular}{|c|c|c|c|c|c|c|c|}
\hline $\begin{array}{l}\text { Discri- } \\
\text { minant } \\
\text { Function }\end{array}$ & $\begin{array}{l}\text { Eigen- } \\
\text { value }\end{array}$ & $\begin{array}{l}\text { Relative } \\
\text { Percen- } \\
\text { tage }\end{array}$ & $\begin{array}{l}\text { Cano- } \\
\text { nical } \\
\text { Corre- } \\
\text { lation }\end{array}$ & $\begin{array}{l}\text { Functions } \\
\text { Derived }\end{array}$ & $\begin{array}{l}\text { Wilk's } \\
\text { Lambda }\end{array}$ & $\begin{array}{l}\text { Chi- } \\
\text { Square }\end{array}$ & $\begin{array}{l}\text { Signi- } \\
\text { ficance }\end{array}$ \\
\hline & & & & 0 & 0.3835 & 166.78 & 0.000 \\
\hline 1 & 1.584 & 99.42 & 0.783 & 1 & 0.9908 & 1.61 & 0.807 \\
\hline 2 & 0.009 & 0.58 & 0.096 & & & & \\
\hline
\end{tabular}

TABLE XVI

STANDARDIZED DISCRIMINANT FUNCTION COEFFICIENTS

Variable

Function 1

Function 2

Cost

$-0.07211$

0.70162

Distance

0.01949

0.37190

Income

0.09581

$-0.77950$

Duration of Du Occupancy -0.08043

0.25009

School Load

1.00145

$-0.00243$ 
and degree of privacy, group ridership, and operation cost-sharing. Walking and the bicycle were included in one group. The bus and carpool were classed into the second group, while the motorcycle and private car, which had the highest user cost per mile, were placed in group three. The classification attempted will be of the form:

$$
c_{i}=c_{i 0}+c_{i 1} v_{1}+c_{i 2} V_{2}+\ldots \ldots+c_{i 5} v_{5}
$$

where $C_{j}$ is the classification score on the discriminant function $i$, the $c_{i j}$ 's represent the classification coefficients, the $V$ 's are the standard values of the five discriminating variables, and $c_{i 0}$ is some constant.

The results of the analysis are shown in tables XV and XVI. In table XV it can be noted that there was a significant chi-square value before the extraction of any discriminant function. This means that there was therefore considerable discriminating power existing among the variables. With respect to the relative ability of each discriminant function to separate the groups, it can be noted that function 1 , with an eigenvalue of 1.584 and associated canonical correlation of 0.783 , accounts for $99.42 \%$ of the total discriminating power, which renders subsequent functions almost useless.

From the standardized discriminant function coefficients (Table XVI), function $l$ is seen to be almost entirely a school load function, while function 2 is a combination of income, cost, and distance 
TABLE XVII

PREDICTION RESULTS

\begin{tabular}{ccccc}
\hline $\begin{array}{c}\text { Actual } \\
\text { Group }\end{array}$ & $\begin{array}{c}\text { Number } \\
\text { of } \\
\text { Cases }\end{array}$ & \multicolumn{3}{c}{ Predicted Group Membership } \\
\hline 1 & 48 & $4^{*}$ & $\begin{array}{c}20 \\
(41.7)\end{array}$ & $\begin{array}{c}24 \\
(50.0)\end{array}$ \\
2 & 165 & $\begin{array}{c}44 \\
(26.7)\end{array}$ & $\begin{array}{c}114 \\
(69.2)\end{array}$ & $\begin{array}{c}7 \\
(4.1)\end{array}$ \\
3 & 148 & 3 & 1 & 144 \\
& & $(2.1)$ & $(0.7)$ & $(97.2)$ \\
\hline
\end{tabular}

*Percentages are indicated in brackets

respectively. Regarding these two functions, the $i$ 's in the classification equation maintain values of 1 and 2 respectively, corresponding to the two functions. Function 2 may be discarded on the basis of insignificance. So that the equation becomes:

$$
\begin{array}{r}
c=(-0.07211) x_{0}+(0.01949) x_{1}+(0.09581) x_{3}+ \\
(-0.08043) x_{5}+(1.00145) x_{7}
\end{array}
$$

where the $X$ 's denote the standardized values of the respective variables.

It seems from the prediction results (Table XVII) that although a very high percentage of the grouped cases were correctly classified $(87.15 \%)$, groups two and three were more predictable than group one. Only $8.3 \%$ of all group one correctly belong there, while $50 \%$ would 
otherwise belong to group three, and $41.7 \%$ to group two. In the second and third groups, $69.2 \%$ and $97.2 \%$ respectively were correctly classified. Regarding the limitations of the survey and the problems encountered in the acquisition of the data, the prediction results reflect, as much as possible, the likelihood or probablity of membership in especially the last two mode groupings. 


\section{CHAPTER $V$}

\section{SUMMARY}

The approach of this paper has been one of a methodological nature. In chapter I, the study of the choice of transport modes by Portland State University students was stated as the problem. The research comprised primarily of survey research among a sample of students totalling approximately $2.14 \%$ of the Fall 1979 enroliment of Portland State University. Complementing the survey were a series of interviews with personnel of Tri-Met as well as other people within the campus. In the student questionnaire, the issues questioned were, among others, the distance between home and school, the optimum time taken to cover it, the kind or kinds of mode used to school, the average income of the student per annum, the number and duration of occupancy of present dwelling unit, and school load of courses taken during Fall term 1979.

Some of the literature reviewed revealed work done on major modes and route-specific situations. In other instances discussions of distances and routes taken by worker-drivers were studied. The on ly study which looked into psychological factors influencing modechoice was a review of findings of other social researchers on major modes of transport such as air, sea, road and rail transport modes.

At the local level, Bahls (1972) made a very useful survey among students, faculty and staff of Portland State regarding their modes of 
transport, parking habits and use of the three park-and-ride facilities then serving the university, with the ultimate results of the need for additional parking facilities as well as spreading out class schedules to incorporate periods outside of rush hour traffic time. Much of the transportation planning work undertaken by the Columbia Region Association of Governments (CRAG) and the Metropolitan Service District (MSD) was also reviewed.

Chapter II of the paper addressed the issue of the transportation modes currently used by students. Attention was also focused on such issues and provisions as campus housing which coutd and did alleviate some of the problems faced due to the separation of home from school. Of the major modes considered, the advantages and disadvantages of using each one were reviewed. In addition, the possibility of the choice of another mode due to physical or other limitations was also studied. The opportunities and constraints of physically handicapped students were also examined.

In chapter III, the historical development of the public transit system in Portland since around 1871 was researched. The numerous changes through which the management of public transit has undergone were analysed. Several of the companies, partnerships and franchises were known to have faced several disadvantages and administrative problems which brewed frequent strikes and led eventually to the closure of the respective organizations. The last two major systems prior to the establishment of Tri-Met were examined in a bit more detail. Of special consideration were the labor management problems 
and wage disparities which existed in comparison to wage earnings in other transit systems.

Tri-Met was officially formed on October 14, 1969, to succeed Rose City Transit Company. It was formed by public law as a municipal corporation to serve the tri-county metropolitan area of Portland. Being provided with a taxing right and federal subsidies, much of its financial constraints were taken care of. It was then in good stead to keep bus fares to a reasonable minimum, thus providing a reasonable consumer surplus to the variety of people it serves.

In establishing its routes around the metropolitan area, Tri-Met has adopted a radial pattern of routing with specific buses serving specific sectors of the service area. The city center with the mall has been made the most accessible point, serving as the center of radiation. As a result, passengers desiring to travel from one sector to another are obliged to make their connection at the mall, with the result that most passengers travel longer distances than would otherwise be expected. In this regard there has been the need for the execution of grid-like connections and circumferential services between major radiating routes.

Like other passengers, students travelling to Portland State University have faced equal transport constraints, especially as regards covering the distance between the mall and the school. While some students walk this distance, others crowd the few buses plying along Broadway to the Medical School or the west end of the city. This further creates a problem as passengers who may want to travel. 
with these buses to destinations farther than the campus location are occasionally left behind. However, other problems that may have arisen if the university were situated somewhere else tend to be ameliorated by the location close to the city center.

For those students using other modes of transport, the most significant singular problem affecting all is the parking problem. Bicycle parking spaces are located between Neuberger Hal1, Smith Memorial Center and Cramer Hall. There is no fee charged. However, they are restrictingly few and available on first-come first-served basis. Motorcycle parking spaces are located along the streets among other automobile parking sites monitored by the City of Portland. One space may accommodate as many as four motorbikes with a shared cost of approximately $\$ 0.30$ apiece for a sixhour period.

With a student population of over 16,000 and several staff and other support personnel, there are at present less than 3,000 parking spaces for cars within the campus. Many students use the public bus, but as many others drive private cars to school, sometimes travelling distances of over 20-30 miles. As a matter of fact one student in the survey travel led about fifty miles to school.

Parking problems in the school have not only forced several students to turn to public transport, but they have also necessitated the adoption by students of the simplest form of mixed-mode transportation. Some travel by car for a distance and secure the cheapest parking facility, and then either walk the rest of the distance or 
join the Tri-Met bus to school.

The fourth chapter of the paper outlines the survey and analysis of the acquired data. The sample was justifiably representative as evidenced by the many departments whose majors were represented. Based on the location of their residences, the number of students in Portland State University that came from each section of the city was related to the resident population in the respective section. Northwest and Southwest Portland had over twice the number of students relative to the resident population. Approximately $41.6 \%$ of the students use the Tri-Met bus to school. The use of the private car featured to about $39.9 \%$ while an additional $4.2 \%$ carpooled to school. A proportion of about $10.5 \%$ walked, while approximately $2.8 \%$ and $1.1 \%$ rode the bicycle and motorcycle to school during Fall term 1979.

The effect of increasing distance on cost tended to be buffered by the broad zones of the public bus service. Within zone III, for instance, many students paid about $0.65 \$$ for an average distance of about 10 miles. In other modes, however, where cost of one-way transportation to school was over $\$ 1.00$ for distances of four miles and over, there was generally a direct correlation between distance and cost of transportation.

One of the two methods of analysis was a multiple linear regression analysis in which cost of one way transportation to school (including daily parking) was used as the criterion variable against serveral other independent variables. The relationship between them 
was rather weak but positively correlated. In the second analysis, mode was used as the dependent variable against those variables which proved significant in the first analysis. This analysis revealed correct classification for only the last two of the three groups classified. This means that the characteristics of the users of the first mode (walking) tended to reflect more of those of the second and third respectively.

\section{Conclusions}

In general, finding from the study may be summarized in the following points:

(1) Based on the survey data, a direct relationship exists between transportation and parking cost and the type of mode used. Transportation cost per unit distance decreases with increasing distance from school, probably because of the broad zones of the Tri-Met bus service as well as the fixed parking cost per day regardless of the distance covered by the student. So that students driving from more distant areas tend to benefit more in terms of parking char. ges than those travelling short distances to school.

(2) Mode-choice was found to be influenced respectively by transportation cost, student income and student course load. Distance between home and school does not seem to influence mode-choice.

(3) Students in the middle income groups were found to live 
farthest from school. Income is the most significant variable in cost prediction.

(4) Travel time per unit distance tends to decrease with increasing cost of transportation.

(5) The Fareless Square around downtown Portland (which includes PSU) provides useful service to students and influences many in using public transit.

(6) Duration of occupancy of residence while attending Portland State is negatively correlated with overall cost of transportation. In other words, the Tonger a student tends to stay at the same place the less he tended to pay for transportation to school.

(7) No relationship was found between frequency of bus service and mode-choice. However public transit operates chiefly in radial sectors of the city with the downtwon Mall as the common meeting point. The design is basically for movement either inbound or outbound from the CBD. Through the Fareless Square, free movement is enhanced.

(8) In the prediction of modal use, student course load was the most important variable.

While service by Tri-Met is reasonably adequate, one of three possible choices would greatly enhance easy transportation to PSU especially relieving those crowded buses that pass through the school from the mall. The first of these alternatives is the possible extension of the mall to include more city blocks to the south so 
that the south end of the mall is within minutes of walking distance from PSU. A second alternative is that, without extending the mall, a shuttle bus service could be created between the mall and the schoo1. This may be operated at 5-10 minute intervals especially during the morning peak. Finally, in the construction of the light rail transit from Gresham to the downtown mall, an extension to PSU could be considered as another alternative which would alleviate the transit bottleneck between the mall and the school.

Several progressive plans have been proposed by the public transit system. A few of these include the proposal to acquire 150 more normal size buses, 150 articulated buses, and 26 coaches for the Portland-Gresham railway line by the year 1982. In addition a new across town bus link from Milwaukie to Swan Island was also agreed upon.

\section{Suggestions for Future Research}

Future lines of research on student transportation in Portland may include the consideration of a few more variables which need to be redefined and screened in an attempt to determine the relationships that may exist among location of school, student residence, mode-choice and transportation cost. Such variables may include the proportion of daytime hours a student spends at school as well as distinguishing between earned income and grants. In order to arrive at a more accurate prediction of student mode-choice in Portland, one or two other schools of different location need to be 
included in a larger study. A third consideration involves the possible exclusion of those students who walk to school in order to correct errors introduced in the quantification due to their zero transportation cost, with the assumption that if one walks to school, the location of his residence is too close to school to allow for a profitable use of any other mode. If on the other hand a student walks to school because he cannot afford the cost of a more economical mode, then that subject should be included in the study. 


\section{BIBLIOGRAPHY}

Amick, D. J., and Walberg, H. J., 1975, Introductory Multivariate Analysis. Berkeley: McCutchan Publishing Corporation.

Bahls, Harold W., 1972, "Transportation Study." Columbia Research Institute. Portland: Portland State University.

Balshone, Bruce L. et al., 1975, Bicycle Transit: Its Planning and Design. New York: Praeger Publishers Inc.

Barber, William D., 1978, "The Bicycle as an Alternative Mode of Urban Transportation." Portland: Portland State University, Department of Geography (Unpublished).

Blunden, W. R., 1973, The Land Use/Transport System. Oxford: Pergamon Press.

Brambilla, Roberto, and Longo, Gianni, 1977, For Pedestrians Only: Planning, Design, and Management of Traffic-Free Zones. New York: Watson-Guptill Publications.

Chorley, R. J., and Haggett, P. eds., 1967, Models in Geography. London: Methuen \& Co. Ltd. Ltd.

, 1969, Integrated Models in Geography. London: Methuen \& Co.

Cole, J. P., and King, C. A. M., 1968, Quantitative :Geography: Techniques and Theories in Geography. London: John Wiley and Sons Ltd.

Columbia Region Association of Governments, 1974a, Annual Report, 1973-74. Portland: Columbia Region Association of Governments.

1974b, A Bike Plan for the Columbia-Willamette Region: Draft Review and Comment. Portland: Columbia Region Association of Governments.

, 1977, "Population Characteristics of the Transportation Handicapped in the CRAG Region." Special Transportation Report No. 2. Portland: Columbia Region Association of Governments.

, 1978a, The Inner Southeast Subarea. Portland: Columbia Region As sociation of Governments. 
Columbia Region Association of Governments, 1978b, The Inner Southwest Subarea. Portland: Columbia Region Association of Governments.

, 1978c, The Northeast Subarea. Portland: Columbia Region As sociation of Governments.

, 1978d, The Northwest Subarea. Portland: Columbia Region As sociation of Governments.

Cooley, W. 'H., and Lohnes, P. R., 1971, Multivariate Data Analys is. New York: John Wiley \& Sons Inc.

Dawson, John A., and Unwin, David J., 1976, Computing for Geographers. Newton Abbot: David and Charles.

De Geer, Van, 1971, Introduction to Multivariate Analys is for the Social Sciences. San Francisco: W. H. Freeman and Company.

DuBois, P. H., 1957, Multivariate Correlational Analysis. New York: Harper and Brothers Publishers.

Ebdon, David, 1977, Statistics in Geography: A Practical Approach. Oxford: Basil Blackwell.

Gassaway, Alexander, R., 1979, "The Adequacy of Facilities for Pedestrian Movement along Motorways in a Section of Portland, Oregon," Portland: Oregon Academy of Sciences.

Gorsuch, R. L., 1974, Factor Analysis. Philadelphia: W. B. Saunders \& Company.

Haggett, Peter, 1966, Locational Analys is in Human Geography. New York: St. Martin's Press.

Haggett, Peter, and Chorley, Richard J., 1969, Network Analys is in Geography. London: Edward Arnold (Publishers) Ltd.

Hammond, R., and McCullagh, P.S., 1974, Quantitative Techniques in Geography: An Introduction. Oxford: Clarendon Press.

Hecht, A., 1974, "The Journey-to-Work Distance in Relation to the Socio-Economic Characteristics of Workers, "Canadian Geographer $18,367-378$.

Horst, Paul, 1965, Factor Analys is of Data Matrices. New York: Holt, Rinehart and Winston, Inc. 
Jacobs, Jane, 1961, The Death and Life of Great American Cities. New York: Alfred A. Knopf, Inc.

Landis, Mark, 1978, "Rucus at Portland." Paper Presented at the APTA Western Conference held in Calgary, Canada.

Lapin, Howard S.,1964, Structuring the Journey to Work. Philadelphia: University of Pennsylvania Press.

Lawley, D. N., and Maxwe 11, A. E., 1963, Factor Analysis as a Statistical Method. London: Butterworths Publications.

McFadgen, Dianna G., 1975, "Transportation Mode-Choice Research: Recent Contributions from the Social Sciences." Travel Demand Forecas ting Project. University of California, Berkeley.

Metropolitan Association of Urban Designers and Environmental Planners, 1974, Proceedings of the Seminar on Bicycle/Pedestrian Planning and Design. Florida: Wait Disney World.

Murdie, Robert A., Factorial Ecology of Metropolitan Toronto, 1951-61: An Essay on the Social Geography of the City. Chicago: University of Chicago Press.

National Research Council, 1971, Highway Research Record: Choice of Trave 1 Mode and Considerations in Travel Forecasting - 19 Reports. Washington, D.C.: National Academy of Sciences.

Nie, Norman H. et al., 1975, Statistical Package for the Social Sciences. New York: McGraw-Hill Book Company.

Oregon Department of Transportation (ODOT), 1973, Oregon Bikeways: Progress Report. Salem, Ore.: Highway Division.

, 1975, Oregon Foothpaths and Bikeways: Progress Report. Salem, Ore.: Highway Division.

Oregon, State of, 1967, Oregon Revised Statutes (ORS) - 1967 Replacement Parts. Vol. 2. Salem, Ore.: State of Oregon.

Oregonian, 1969, "Council Passes Agreement, Strike Abated: Tri-Met to Assume Operations; Spokesmen Plan New Vehicles." Vol. CIX, 34, 104. Portland, Ore.: The Oregonian Press.

Owen, Wilfred, 1966, The Metropolitan Transportation Problem. Washington, D.C.: The Brookings Institution. 
Portland Bicycle Paths Task Force, 1973, Bicycle Facilities for Portland: A Comprehensive Plan. Portland, Oregon.

Quandt, Richard E. ed., 1970, The Demand for Travel: Theory and Measurement. Lexington, Massachusetts: D. C. Heath \& Company.

Scarlett, Maurice J., 1971, "Dynamic Programming and the Solution of a Problem in Urban Transportation." Canadian Geographer 15, 1-12.

Schilderinck, J. H. F., 1969, Factor Analys is Applied to Developed and Developing Countries. Groningen: Rotterdam University Press.

Tri-Metropolitan Transit Corporation (Tri-Met), 1979a, City Lines Legend. Port land, Oregon: Tri-Met.

, 1979b, "Planning with Transit: Land Use and Transportation Planning Co-ordination." Portland, Oregon: Tri-Met.

, 1979c, "The Going Options." Consumer Development Newsletter. Vo1. 3, No. 5, Portiand, Oregon: Tri-Met. , 1979d, "Tri-Met Fact Sheet." Portland, Oregon: Tri-Met

Willard, Patricia B., 1977, "Data Collection Techniques for a Transit Study at a Major Activity Center." M.S. Thesis, University of Maryland.

Yost, Jack, 1980, "Free Rides Axed." The Vanguard. Vol. 35, No.39, Portland, Oregon: Portland State University. 


\section{APPENDIX}

The Survey Questionnaire 
THE JOURNEY TO SCHOOL: A STUDY ON STUDENT TRANSPORTATION

PORTLAND STATE UNIVERSITY

Department of Geography

October, 1979 
1. Where do you presently live?

North Portland $\ldots \ldots \ldots \ldots \ldots \ldots \ldots, \ldots, 1$

North-East Portiand $\ldots \ldots \ldots \ldots \ldots \ldots .2$

North-West Portland $\ldots \ldots \ldots \ldots \ldots \ldots . .3$

South-East Portland $\ldots \ldots \ldots \ldots \ldots \ldots, 4$

South-West Portland $\ldots \ldots \ldots \ldots \ldots \ldots \ldots 5$

other (Please state below) ...........6 6

Please state your exact street address including the zip code.

2. When did you move to your present location?

3. How far away is your dwelling unit (DU) from Portland State University (PSU)?

Less than one mile $\ldots \ldots \ldots \ldots \ldots \ldots$. 1

$1-2$ miles $\ldots \ldots \ldots \ldots \ldots \ldots \ldots \ldots \ldots .2$

$3-5$ miles ..................... 3

6 - 10 miles $\ldots \ldots \ldots \ldots \ldots \ldots \ldots \ldots . .4$

Over ten miles ................... 5

Please state the exact distance

4. How many hours of credit do you currently take at PSU? (credit-hours) 
5. At what time of the day do you have classes?

always usualiy sometimes never

Morning (7:30-12 noon)

Afternoon (12:00-5:00 p.m.).....

Night (5:00-10:00 p.m.)

6. How important is any one of the following reasons in determining the choice of your DU?

$\begin{array}{lll}\text { very } & \text { somewhat } & \text { not at all } \\ \text { important } & \text { important } & \text { important }\end{array}$

Close to school

Far away from school

Easily accessible to

school by bus

Inexpensive housing

Quiet environment

Living with parents or relatives

Living in personal/

family house

Other reason

(Please state below)

7. How long have you lived where you currently live while attending PSU?

One quarter

Two quarters $\ldots \ldots \ldots \ldots \ldots . . .2$

One year $\ldots \ldots \ldots \ldots \ldots \ldots . \ldots . \cdots$

Two years $\ldots \ldots \ldots \ldots \ldots \ldots . .4$

Over two years $\ldots \ldots \ldots \ldots \ldots . . .5$ 
8. If you have changed your DU within the last two quarters, did you move farther away from or closer to school

Closer

Farther away

Approximately some distance ........... 3

9. Do you share your present DU with any other person, and if so, is that person a student either at P.S.U. or some other school?

P.S.U.

student

Yes

No student at other school

10. Do you walk, ride or drive to school with the friend with whom you share your DU or with some other friend?

Travel all the way to school
Travel part of the way to school

with DU

sharer

with other

friend

with no one else

11. How do you currently travel to school?

always usually sometimes never

Walking

Riding bicycle

Riding motor-bicycle/

motor-cycle

Driving private car

Offered ride

Hitchiniking

Using carpool

Using Tri-Met bus 
Other (specify)

12. How long does it take you to get to school?

Less than 15 minutes $\ldots \ldots \ldots \ldots \ldots \ldots \ldots$.

$15-29$ minutes $\ldots \ldots \ldots \ldots \ldots \ldots \ldots \ldots \ldots \ldots \ldots$

$30-44$ minutes $\ldots \ldots \ldots \ldots \ldots \ldots \ldots \ldots \ldots \ldots$

45 minutes to one hour $\ldots \ldots \ldots \ldots \ldots \ldots \ldots 4$

Over one hour $\ldots \ldots \ldots \ldots \ldots \ldots \ldots \ldots \ldots$

Please state exact time $\quad \ldots \ldots \ldots$....hrs. ........mins.

13. How much does it cost to make a one-way trip to or from school, that is, what does it cost you collectively for bus, gas, car-rent, parking permit or other expenses?

Free bus ride (Free zone) $\ldots \ldots \ldots \ldots \ldots \ldots$.

$\$ 0.45 \$$ bus ticket (Zone 2) $\ldots \ldots \ldots \ldots \ldots \ldots 2$

$\$ 0.45 \$$ bus ticket plus transfer ........... 3

$\$ 0.65 \$$ bus ticket (Zone 3) .............4

Gas $(\operatorname{cost} \ldots .)+$. depreciation $0.17 \phi /$ mile $x$ no. of miles $(=\ldots \ldots \ldots \ldots \ldots . . . \ldots 5$

Car-rent (cost per day $\ldots \ldots \ldots \ldots)$........6 6

Parking (cost per day ................ 7

Other (please state $\ldots \ldots \ldots \ldots \ldots$........ 8

14. If you use a private car, for what other purposes do you use it besides travelling to school?

Going to work ...............

Going to some other school .......2

Recreation $. . \ldots \ldots \ldots \ldots \ldots \ldots . \ldots 3$

Shopping $\ldots \ldots \ldots \ldots \ldots \ldots \ldots \ldots$

other $(\ldots \ldots \ldots \ldots \ldots) \ldots \ldots$ 
15. If you have changed transportation means to school while attending P.S.U., what was your old means of transport?

$$
\text { always usually sometime never }
$$

Walking
Riding bicycle
Riding motor-bicycle/
motor-cycle
Driving private car
Offered ride
Hitch-hiking
Using carpool
Using TRI-MET bus
Other (please specify
below)

16. Are you employed either full-time or part-time at school, at home (self-employed) or somewhere else?

$$
\text { at school at home somewhere else }
$$

Full-time

Part-time

Not employed

17. Which of these groups best describes your annual income?

$$
\begin{aligned}
& \text { A } \ldots \ldots \ldots \ldots \text {............ Less than } \$ 2,500 \\
& \text { B } \ldots \ldots \ldots \ldots \ldots \ldots \ldots \$ 2,500-\$ 4,999 \\
& \text { C .............. \$5,000 - \$7,499 } \\
& \text { D ............. \$7,500 - \$9,999 } \\
& \text { E ............. \$10,000-\$12,499 } \\
& \text { F } \ldots \ldots \ldots \ldots \ldots \text { Over } \$ 12,500
\end{aligned}
$$


18. Does your job have anything to do with your living place, i.e. is your job very important, somewhat important or not at all important in determining your living place?

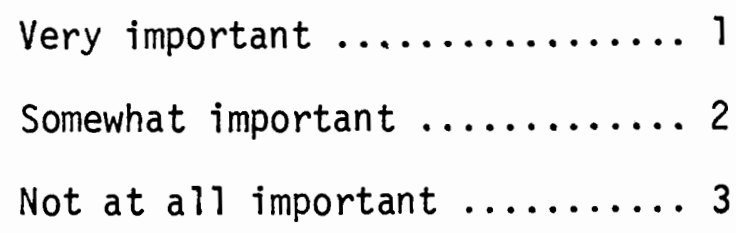

If it is somewhat or very important, please explain how.

19. Does your present job depend very much, somewhat or not at all on your attendance at P.S.U?

Very much $\ldots \ldots \ldots \ldots \ldots \ldots \ldots$. 1

Somewhat $\ldots \ldots \ldots \ldots \ldots \ldots \ldots$

Not at all $\ldots \ldots \ldots \ldots \ldots \ldots$

20. Is the selection of your DU a compromise choice between school and job, or between two school campuses you may be attending simultaneously?

Between school and job........ I

Between two schools ......... 2

DU has no bearing on

either school or job........ 3

21. What is your major?

22. What comments, criticisms, suggestions or contributions do you have regarding transportation to school and related problems? 